\title{
Water Resources Studies in Headwaters of the Blue Nile Basin: A Review with Emphasis on Lake Water Balance and Hydrogeological Characterization
}

\author{
Alemu Yenehun ${ }^{1,2}, * \mathbb{D}$, Mekete Dessie ${ }^{3}$, Mulugeta Azeze ${ }^{3}$, Fenta Nigate ${ }^{1,2}$, Ashebir Sewale Belay ${ }^{1,2} \mathbb{D}$,

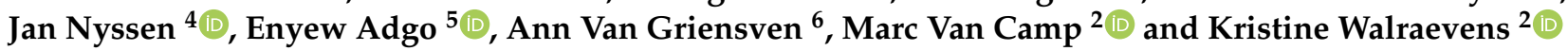 \\ 1 School of Earth Sciences, Bahir Dar University, P.O. Box 79, Bahir Dar 6000, Ethiopia; \\ fentanigate@gmail.com (F.N.); AshebirSewale.Belay@ugent.be (A.S.B.) \\ 2 Laboratory for Applied Geology and Hydrogeology, Department of Geology, Ghent University, Krijgslaan \\ 281 (S8), B-9000 Ghent, Belgium; Marc.VanCamp@ugent.be (M.V.C.); kristine.Walraevens@ugent.be (K.W.) \\ 3 Faculty of Civil and Water Resources Engineering, Bahir Dar University, P.O. Box 430, \\ Bahir Dar 6000, Ethiopia; mekete95@yahoo.com (M.D.); mulugetaazeze94@gmail.com (M.A.) \\ 4 Department of Geography, Ghent University, Krijgslaan 281 (S8), B-9000 Ghent, Belgium; \\ Jan.Nyssen@ugent.be \\ 5 Department of Natural Resource, Bahir Dar University, P.O. Box 79, Bahir Dar 6000, Ethiopia; \\ enyewadgo@gmail.com \\ 6 Department of Hydrology and Hydraulic Engineering, Faculty of Engineering, Vrije Universiteit Brussel, \\ Pleinlaan 2, 1050 Brussels, Belgium; ann.vangriensven@gmail.com \\ check for \\ * Correspondence: AlemuYenehun.Beyene@UGent.be; Tel.: +251-938-884476
}

updates

Citation: Yenehun, A.; Dessie, M.; Azeze, M.; Nigate, F.; Belay, A.S.;

Nyssen, J.; Adgo, E.; Van Griensven, A.; Van Camp, M.; Walraevens, $\mathrm{K}$.

Water Resources Studies in

Headwaters of the Blue Nile Basin: A Review with Emphasis on Lake Water Balance and Hydrogeological Characterization. Water 2021, 13, 1469 https://doi.org/10.3390/w13111469

Academic Editor: Cesar Andrade

Received: 18 February 2021

Accepted: 21 May 2021

Published: 24 May 2021

Publisher's Note: MDPI stays neutral with regard to jurisdictional claims in published maps and institutional affiliations.

Copyright: (c) 2021 by the authors Licensee MDPI, Basel, Switzerland. This article is an open access article distributed under the terms and conditions of the Creative Commons Attribution (CC BY) license (https:// creativecommons.org/licenses/by/ $4.0 /)$.

\begin{abstract}
The Lake Tana Basin, comprising the largest natural lake in Ethiopia, is the source and the uppermost part of the Upper Blue Nile Basin. In this review paper, research papers, mainly on the rainfall-runoff modeling and lake water balance, and on the hydrogeology, have been reviewed. The earlier water balance estimation attempts used simple conceptual and statistical approaches and calculate on a monthly timescale. More recent research has been using advanced semi-physically or physically based distributed hydrological models. Accordingly, mean annual precipitation over the lake was estimated in the range $36.1-53.1 \%$; lake evaporation at $45.3-57.5 \%$; river inflow (all gauged and estimated ungauged) at $43.6-63.9 \%$; and river (lake) water outflow at $0-9.2 \%$. With the few isotope studies, groundwater inflow and outflow are found insignificant. Different studies had estimated groundwater recharge, ranging from $57 \mathrm{~mm}$ to $850 \mathrm{~mm}$. The basin has a heterogenous aquifer system consisting of different volcanic rocks and alluvio-lacustrine sediments. Generally, groundwater with low TDS, $\mathrm{Ca}-\mathrm{Mg}-\mathrm{HCO}_{3}$ type, isotopically relatively enriched, and high TDS, $\mathrm{Na}-\mathrm{HCO}_{3}$ type, isotopically relatively depleted, water types have been identified. In this paper, major research gaps such as aquifer hydraulic characterization, surface-groundwater interaction, groundwater flow and groundwater balance have been identified. Hence, future research shall focus on the groundwater resources, so that existing surface water studies are updated and future water usage options are explored.
\end{abstract}

Keywords: Lake Tana Basin; water balance; hydrogeology; aquifer; recharge; research gap

\section{Introduction}

Consumptive uses of the Nile River water had been rapidly increasing over the last century, and demand projection shows a significant increase that may exceed the average annual supplies [1]. Population growth (expected to be double by 2050), urbanization, irrigation expansion (an anticipated increase of $60-70 \%$ in the coming decade), extreme poverty and lack of alternative livelihoods, high seasonal flow variability, environmental degradation, low land productivity, and lack of adequate infrastructural management will result in increasing pressure on the limited water resources of the river basin [2]. 
Furthermore, many studies (e.g., [3-5]) showed that several parts of the Nile Basin are sensitive to variations of climatic variables suggesting that climate change will have a significant impact on its water resources. The transboundary nature of the Nile waters reveals the interconnectedness of the Nile states, which rely upon the Nile ecosystem not only for economic, social and cultural needs but also for the maintenance of peace and security in the region [6]. Since recent years, the hegemony of Egypt over the Nile River is changing, and the hydropolitics has entered into a new dynamism [7]. For example, the flow dynamics of the Blue Nile River (contributing about $87 \%$ of the Nile River water) will be changed due to the construction of a big dam reservoir, named the Grand Ethiopian Renaissance Dam (GERD) [8]. Through this dam, Ethiopia aims at providing access to electricity for its citizens while also becoming the energy hub in the region and sell cheap energy for the other Eastern Africa countries [2]. The dam is near completion and will be the biggest dam in Africa. Though it is primarily for power generation purposes rather than for consumptive use, its operations will change downstream flow patterns significantly [8]. This dam filling and future operation is the current hot political issue of the region and the hydropolitics of the world. Lake Tana is the source of the upper Blue Nile River which is the major tributary to the Nile River. The Nile Basin is shared by eleven riparian countries and is the lifeline for more than 238 million people living in the basin $[9,10]$.

The Lake Tana Basin (Figure 1) has a total drainage area of approximately $15,077 \mathrm{~km}^{2}$, of which Lake Tana, the largest natural lake in Ethiopia, covers about $3077 \mathrm{~km}^{2}$. Lake Tana is situated in the northwestern Ethiopian highlands and receives flow from more than 40 rivers [11-14]. It has an average depth of about $9 \mathrm{~m}[12,15,16]$. In addition to the lake's aquatic environment, floodplains that surround the lake in the east, north, and southwest, form extensive wetlands. These wetlands contain heterogeneous habitats that support high biodiversity, leading it to be one of the top 250 lake regions of global importance for biodiversity [17]. Although the Lake Tana Basin has significant importance concerning water resources and the ecological balance of the area, many years of mismanagement, wetland losses due to urban encroachment, population growth, and droughts are causing its rapid deterioration [9]. The land-use/cover changes in the Ethiopian highlands have significantly increased the variability of runoff and sediment fluxes of the Blue Nile River during the last few decades [10].

There has been limited water-resources research on the upper Blue Nile Basin in general and Lake Tana Basin, in particular. There are few hydrological, hydrogeological, and climatic data available, which hinders an in-depth assessment of the hydrology and hydro(geo)logy of the basin [18-21]. The first hydrological study on the Lake Tana basin dates back in time to 1903 [22] when a team from Egypt had visited Ethiopia to collect all necessary information and to consider the possibility of converting Lake Tana into a flow-controlled artificial reservoir for irrigation of big cotton and sugar cane farms in Egypt during the dry period (March to July). Later, in 1920, a team of professionals traveled to the lake and collected hydrometeorological data for about four consecutive years [22]. In addition, detailed mapping and survey work of the lake outlet to Blue Nile river, and the lake level had been made successfully. Only recently, the gauged river coverage reached $60 \%$ [12], while the ungauged river water contribution remains one of the major sources of uncertainty in the water balance calculations. Besides, in recent years, the water resource development projects are affecting the flow amount and system (Figure 2). Moreover, rainfall is highly variable spatially and temporally $[10,12,13,23-25]$ but there are few gauging stations measuring precipitation with a daily time scale $[5,11,13,14,26-28]$. 

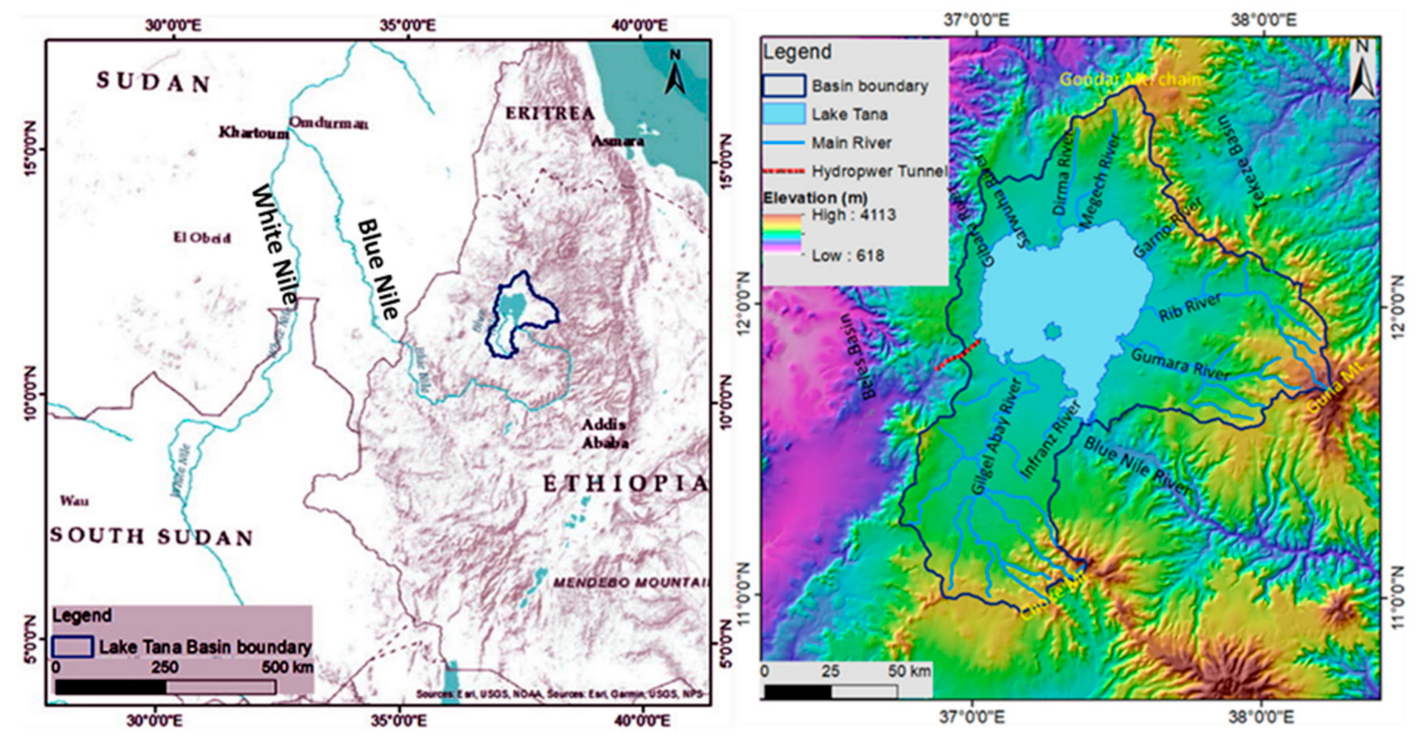

Figure 1. Location map of Lake Tana basin showing the topographical setup and main rivers. The Beles, the Blue Nile and the Tekeze basins are the major adjacent basins for Lake Tana Basin. The lake has two outlets: natural to the Blue Nile and through a tunnel to the Beles basins.

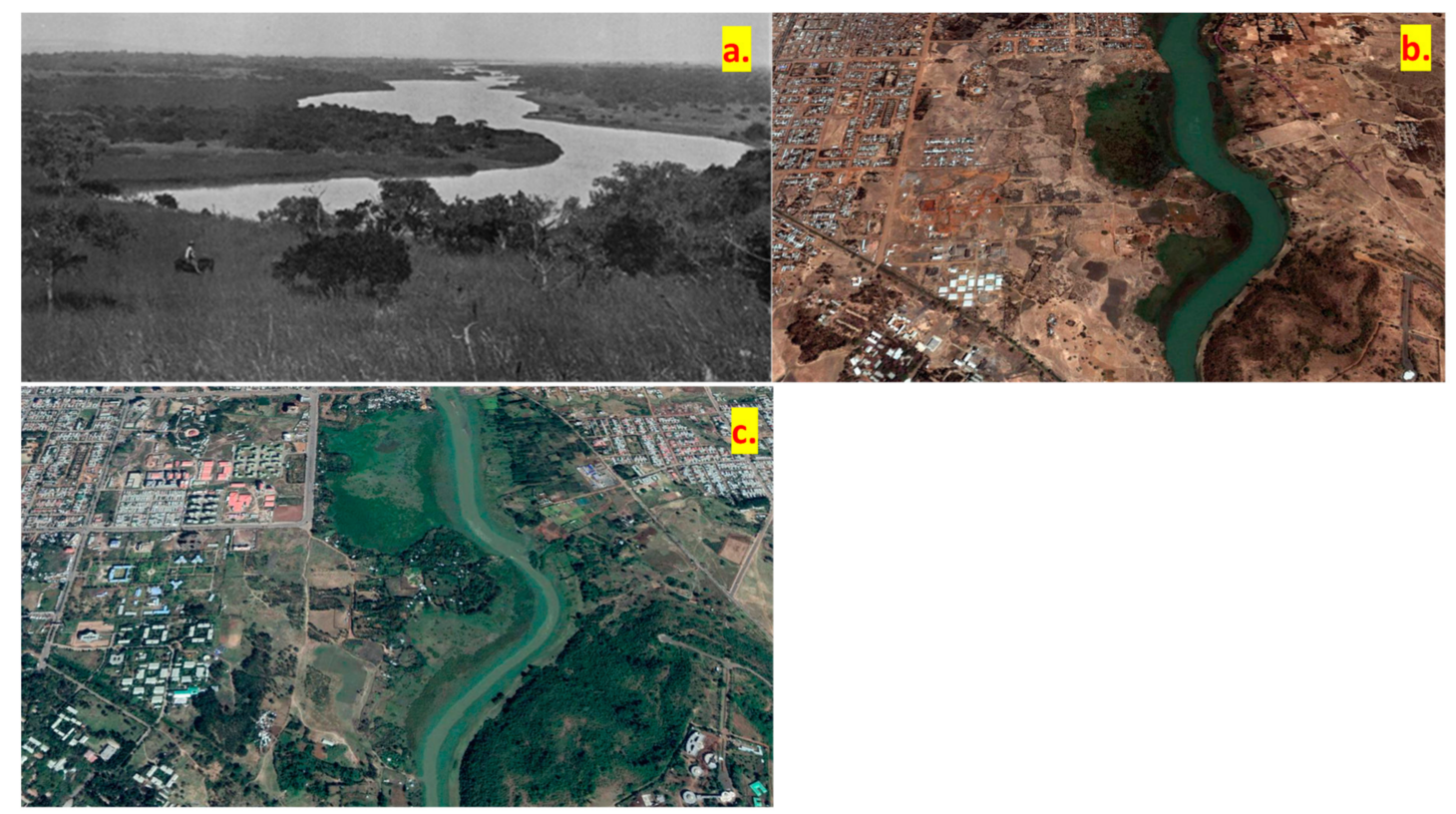

Figure 2. "The Blue Nile channel leading from the outlets of Lake Tana" (looking to the South), as seen in 1920 (Grabham and Black, 1925) (a), Google Earth map of the area taken in 2005 (b), and Google Earth map of the area taken in 2020 (c). A significant amount of the previous watercourse in (c) is exposed, portraying the water flowing out of Lake Tana is reduced due to water transfer to the Beles basin since 2010.

The complex nature of the aquifers, owing to multi-stage volcanism and hence the presence of different volcanic rock varieties (with complex geometry), has hampered the effective production of groundwater in the Lake Tana basin in particular and in the Ethiopian volcanic plateau in general. This might lead to difficulties in locating productive aquifers and sustainably develop the groundwater $[19,29,30]$.

Due to the complex geology, insufficient research attention, lack of financial resources, together with many socio-political reasons, the groundwater database remains very limited. In general, the groundwater component of the Tana Basin has been relatively little studied (e.g., $[19,30,31])$. This study limitation of the groundwater resource is contrary to its 
contribution, especially for drinking water supply. Despite there are many unsuccessful stories in the drilling of productive wells, it is still the important sources of domestic and industrial source of water for the cities and towns of the area. In this review paper, we wanted to show the study gaps and cruciality of future research on the groundwater part by reviewing the existing relatively few research works. Furthermore, in the hydrogeology section, we did not restrict the review articles for only the studies that have been done in the specific area but tried to review papers published in the other parts of the Ethiopian volcanic plateau so that readers understand the groundwater system in a broader perspective.

A summarized and compressive understanding of the surface and groundwater hydrology of the study area is important for the researchers, water managers, policy makers, and political actors of the nation and the region. Understanding what are the main conclusions drawn by different studies, methods followed, and data used, and thus identifying main study limitations will help in facilitating further research in this economic, social, and political important area. This paper presents a review of research works conducted on the water balance and hydrogeological systems of the Lake Tana Basin and identifies gaps yet to be filled. It also provides recommendations for future research. This review mainly focuses on the lake water balance, surface-groundwater interrelation, and hydro(geo)chemistry.

\section{Study Area Description}

The Lake Tana Basin lies in the highlands of the Blue Nile Basin. The climate is strongly influenced by elevation $[3,19]$. The climate of the study region is tropical highland monsoon, with one main rainy season between June and September and with a mean annual amount of $1280 \mathrm{~mm}[18,32,33]$. The air temperature shows large daily but small seasonal changes with an annual average of $20^{\circ} \mathrm{C}$. The Atlantic Ocean is the main source of rainfall in summer but the eastern mountainous parts of the Blue Nile Basin receive rainfall originating from the Indian Ocean in March and April [19], which also rains in Tana Basin to a certain extent.

The Lake Tana Basin is perched on a topographic high part of an uplifted dome that was active during the Tertiary volcanic events [34]. It is located on a faulted depression between the erosional escarpment overlooking the Sudan plains to the west, and the tectonic escarpment of the plateau margin overlooking the Afar depression to the east [34]. Stratified Tertiary volcanic rock piles in northwestern Ethiopia overlie the Mesozoic sedimentary rock stratigraphical sequence where there is a major unconformity between the sequences [34]. They have an average thickness of 1 to $1.5 \mathrm{~km}[35,36]$ and covers a significant area of the basin (Figure 3a). The volcanism for the formation of this Tertiary flood basalt is related to massive crustal warping along the main Ethiopian rift margins that happened during the Quaternary Era [37]. Furthermore, Quaternary basalt covers most of the southern part of the Tana Basin [35] (Figure 3a). The Lake Tana Basin was formed by the junction of three grabens [34]. It acquired its present form through damming by a 10,000-year-old Quaternary lava flow on its southern part [35]. Prave et al. [38] used ages of the different mafic and felsic rocks of the basin and conclude that the basin was formed by central volcanism which formed a 60-80 km diameter caldera, about 1-km deep, contradicting the hypothesis that the basin was formed by the junction of three grabens [34].

The high topography of the upper Blue Nile River Basin is the result of regional uplift, and Tertiary and Quaternary lava flows [39]. During the later stages of volcanism, magmatic outlets became focused and built up large shield volcanoes. The Tana area is also characterized by many dike and pipe feeders [40]. The flat plain, towards the mouth of major rivers to the Lake Tana, is covered by Quaternary lacustrine sediments, reworked with alluvial process (some call it alluvio-lacustrine) (Figure 3a). 


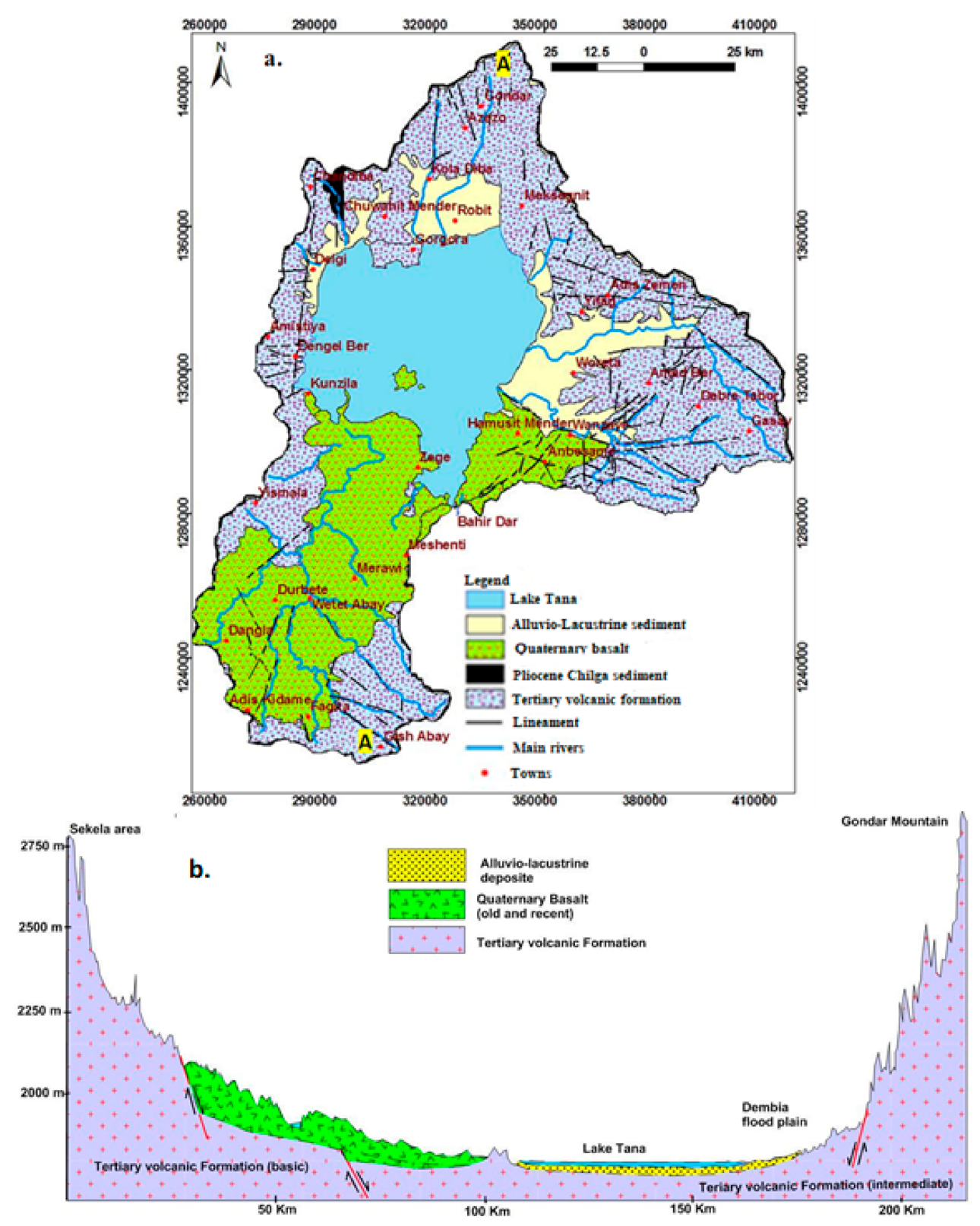

Figure 3. Geological map of Lake Tana Basin (a) and a cross-section from Sekela to Gondar mountain (A-A') (b) modified after Nigate et al. [41], (2017). The UTM zone is 37P and the coordinate system is WGS 1984.

\section{Water Balance}

The first attempt of estimating the water balance of Lake Tana was by Grabham and Black [22] using the hydrometeorological measurements collected from 1920 to 1923 . They estimated the over-lake rainfall and evaporation, annual lake level fluctuation, and lake outflow to the Blue Nile River.

In the recent past, different authors applied different techniques to estimate the water balance of Lake Tana Basin with the available hydrometeorological data at either monthly or daily time steps. Most of them applied distributed physical hydrological models such as SWAT and HBV-96 (e.g., [13,14,33]), while others used simple conceptual process-based hydrological models (e.g., [12]), simple mass conservation, chemical mass balance models (e.g., [30,42]), and simple spreadsheet water balance programs (e.g., [26,28]).

The water balance, which is based on conservation of mass at the lake, should consider river inflow (both from gauged and ungauged catchments), groundwater inflow, and precipitation over the lake as the total inflow to the lake; and lake water evaporation, 
groundwater outflow, and lake water outflow as outflows terms (Figure 4). It is only the lake water outflow, to both the Blue Nile River and through the artificial hydropower tunnel (since May 2010) (Figure 1), that is completely measured. In the other components of the balance equation, significant uncertainties might be incorporated due to some gross assumptions and sparse measured data availability Both estimation and measurement errors could be possibly involved. The reliability of estimated water balance terms depends on the quality of those parameter estimations and measurements. In most of the previous water balance studies, the groundwater inflow and outflow were ignored.

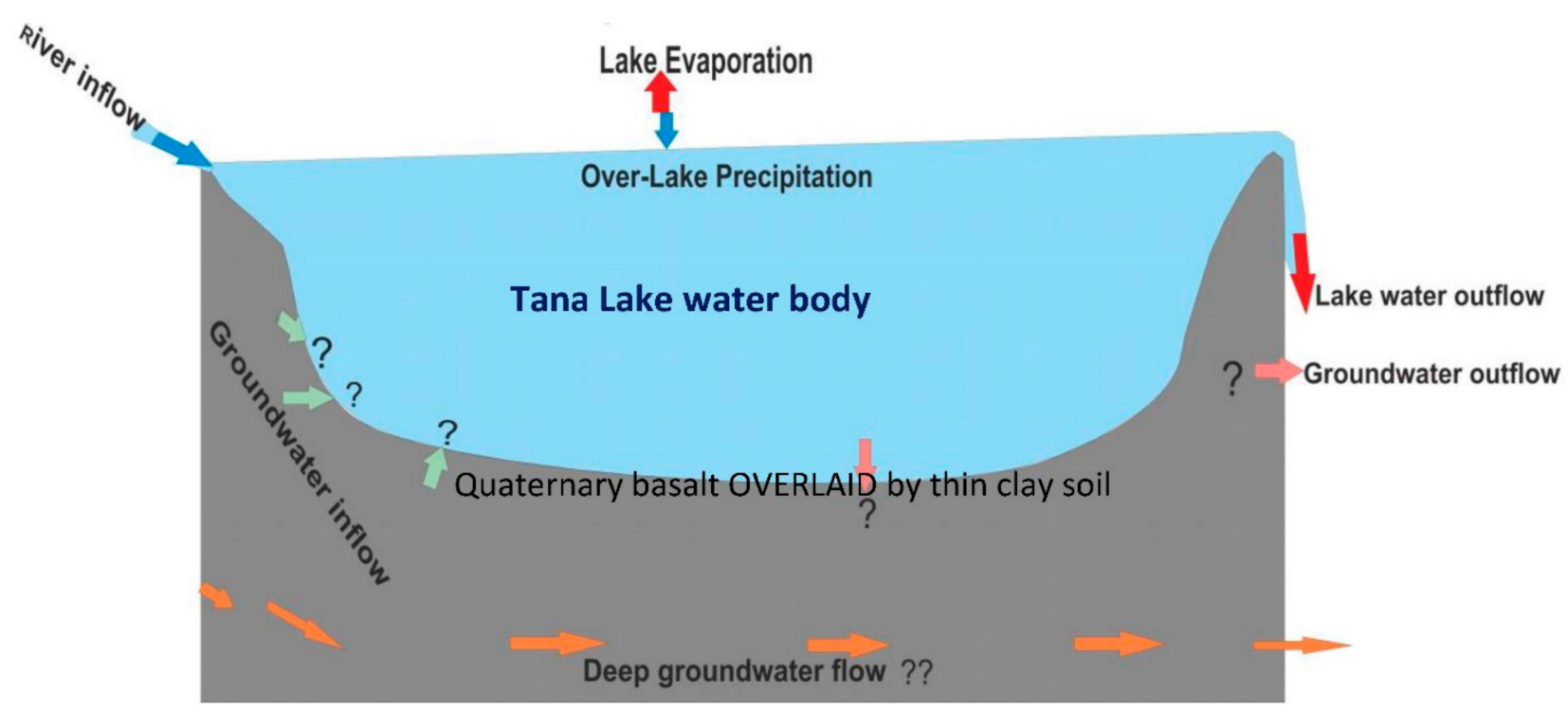

Figure 4. Conceptual diagram depicting possible water balance components at Lake Tana. Uncertainties are indicated by question marks.

Different authors have used different methods and different time scales (monthly or daily) for estimating the precipitation, evaporation and ungauged river flows of Lake Tana; the considered time scale (monthly or daily); the time-series data used (mostly similar period but some differ (e.g., [12,28]); and assumptions considered for simplifications. The following discussion on the water balance of the Lake Tana Basin considers the water balance estimation methods applied, the input and output variables, the assumptions made, and finally the overall resulting lake water balance from the different studies.

\subsection{Precipitation}

In the Lake Tana Basin, the precipitation in the upper catchments has been used as input in the modeling of river discharge, and precipitation on the lake has been used in the water balance calculations. In 1920, the study team from Egypt established a measuring station at Bahir Dar (Figure 3a) for the first time [22]. They observed uneven distribution of rainfall over the basin and as well as over the lake. However, they considered the annual average value of $1290 \mathrm{~mm}$ recorded at Bahir Dar as fairly central and representative. Rientjes et al. [10] used daily rainfall data from seventeen meteorological stations collected from 1994-2003, for the basin-wide spatial interpolation of areal rainfall. According to SMEC [26], the average annual overall basin-wide rainfall, calculated using Inverse Distance Weight (IDW) interpolation method, was $1326 \mathrm{~mm}$. Mamo [30] applied the Thiessen polygon method using long-term (1995-2009) monthly rainfall data from eight stations for the land part of the basin and estimated a value of $1400 \mathrm{~mm}$. Dessie et al. [15] estimated areal rainfall depth from 34 gauging stations using Thiessen polygon, IDW, and Satellitederived Rainfall Estimates (from NOAA). The estimated mean annual basin-wide rainfall amount was $1482 \mathrm{~mm}, 1404 \mathrm{~mm}, 1331 \mathrm{~mm}$, respectively, for the Thiessen polygon, IDW, and satellite-derived methods. Wale et al. [14] used a similar Thiessen polygon method 
for the basin rainfall estimation. A poor correlation of rainfall with topography had been noted by Dessie et al. [11] for Gilgel Abay and Gumara, and by Getenet [43] for Rib, which gives good reasoning for the application Thiessen polygon and IDW method.

Mean annual rainfall over the lake was estimated by different authors. SMEC [26] calculated using the Thiessen polygon and inverse distance weighting (IDW) methods and found mean annual values of $1321 \mathrm{~mm}$ and $1248 \mathrm{~mm}$, respectively (Table 1). The IDW seemed to provide good results rather than the Thiessen polygon method when compared with Tropical Rainfall Measuring Mission (TRMM) satellite data (which is with better spatial resolution but low data acquisition). Rientjes et al. [13] interpolated using IDW squared method to address the higher spatial variability of the rainfall over the lake area. They used daily rainfall from five surrounding meteorological stations and calculated the mean annual value at $1290 \mathrm{~mm}$ (Table 1). Chebud and Melesse [42] used monthly data from similar stations and used ordinary kriging interpolation to estimate an average of $1230 \mathrm{~mm}$. Kebede et al. [28] estimated rainfall by using monthly data in the period 1960-1992 solely from Bahir Dar station and found a value of $1451 \mathrm{~mm}$ while Grabham and Black [22] found $1290 \mathrm{~mm}$ using measured data of 1920-1923 at a similar station (Table 1). Mamo [30] also applied the Thiessen method, using the 1960-1992 data from seven stations (surrounding, and one on Dek island), and estimated the average annual rainfall on Lake Tana to be $1270 \mathrm{~mm}$. Wale et al. [14] used Thiessen polygon, IDW and IDW squared methods. They estimated long-term mean annual rainfall values (Table 1). The one with IDW squared is adapted because high weight was given for the data from Dek Island. Dessie et al. [12] applied Thiessen polygon method using data from six stations on a daily timescale (Table 1).

Table 1. The mean over-lake precipitation estimations made by different authors (applying different methods) for the different periods and time scales.

\begin{tabular}{|c|c|c|c|c|c|}
\hline Literature & Timescale & Data Period & Number of Stations & $\begin{array}{l}\text { Areal Interpolation } \\
\text { Technique Applied }\end{array}$ & $\begin{array}{c}\text { Mean Annual } \\
\text { Over-Lake } \\
\text { Precipitation }(\mathrm{mm})\end{array}$ \\
\hline Grabham and Black [22] & monthly & 1920-1921 & one & Single station & 1290 \\
\hline \multirow{3}{*}{ Wale et al. [14] } & \multirow{3}{*}{ daily } & \multirow{3}{*}{ 1992-2003 } & \multirow{3}{*}{$\operatorname{six}$} & Thiessen polygon & 1229 \\
\hline & & & & IDW squared & 1290 \\
\hline & & & & IDW & 1254 \\
\hline Rientjes et al. [13] & daily & 1994-2003 & five & IDW & 1290 \\
\hline Kebede et al. [28] & daily & 1960-1992 & 1 (Bahir Dar station) & Single station & 1454 \\
\hline \multirow{2}{*}{ SMEC [26] } & \multirow{2}{*}{ monthly } & 1960-2005 & \multirow{2}{*}{$\begin{array}{l}2 \text { (Bahir Dar and } \\
\text { Gondar stations) }\end{array}$} & Thiessen polygon method & 1321 \\
\hline & & 1960-1995 & & IDW & 1248 \\
\hline Mamo [30] & monthly & 1995-2009 & seven & Thiessen polygon & 1230 \\
\hline Setegn et al. [33] & daily & 1978-2004 & $\begin{array}{c}\text { not explicitly } \\
\text { mentioned (probably } \\
\text { Gondar and Bahir Dar) }\end{array}$ & Not mentioned & 1281 \\
\hline Dessie et al. [12] & daily & 2012-2013 & six & Thiessen polygon & 1330 \\
\hline Chebud and Melesse [42] & monthly & 1960-2003 & five & $\begin{array}{l}\text { ordinary kriging } \\
\text { interpolation }\end{array}$ & 1230 \\
\hline
\end{tabular}

There have been no significant trends over the long term in total annual rainfall in the highlands of Ethiopia over the past 30-50 years [44]. However, there is much spatial variability due to high topographical relief. The rainfall has increased in Gondar and decreased in Bahir Dar and Dangila stations (Figure 3a) from1980 to 2016 [23]. The average rainfall is highest in the southern and south-eastern parts of the basin and strongly decreases towards the northern and north-western parts, with an appearance of a marked pattern over the lake [26]. Rainfall in the basin (taking upper Gilgel Abay catchment as a case study) was analyzed by Rientjes et al. [43] on monthly basis using Mann-Kendall test 
statistics. It was found to increase year-to-year during wet season months of June, July, and August while decreasing year-to-year the rest of the months. Future projection of rainfall to 2080s shows a decrease during the beginning of the rainy season (May to June), and an increase during the end of the rainy season (September to October), but with no clear trend in the main rainfall period of July and August [45]. In general, the use of satellite images has shown promising results for poorly-gauged catchments with complex topography in the Upper Blue Nile Basin [46,47]. Compared with a value obtained from Tropical Rainfall Measuring Mission (TRMM) satellite data, the interpolated rainfall using meteorological data has a similar trend of spatial variation but the TRMM estimates are generally lower by $33 \%$ than interpolated [26].

\subsection{Evapotranspiration and Evaporation}

Grabham and Black [22] made direct measurements of the evaporation from Lake Tana for the first time from 1920 to 1921. They had applied evaporimeters of Piche Tube and Tank Evaporimeters (Figure 5) and estimated the mean annual evaporation loss from the lake at $1365 \mathrm{~mm}$.

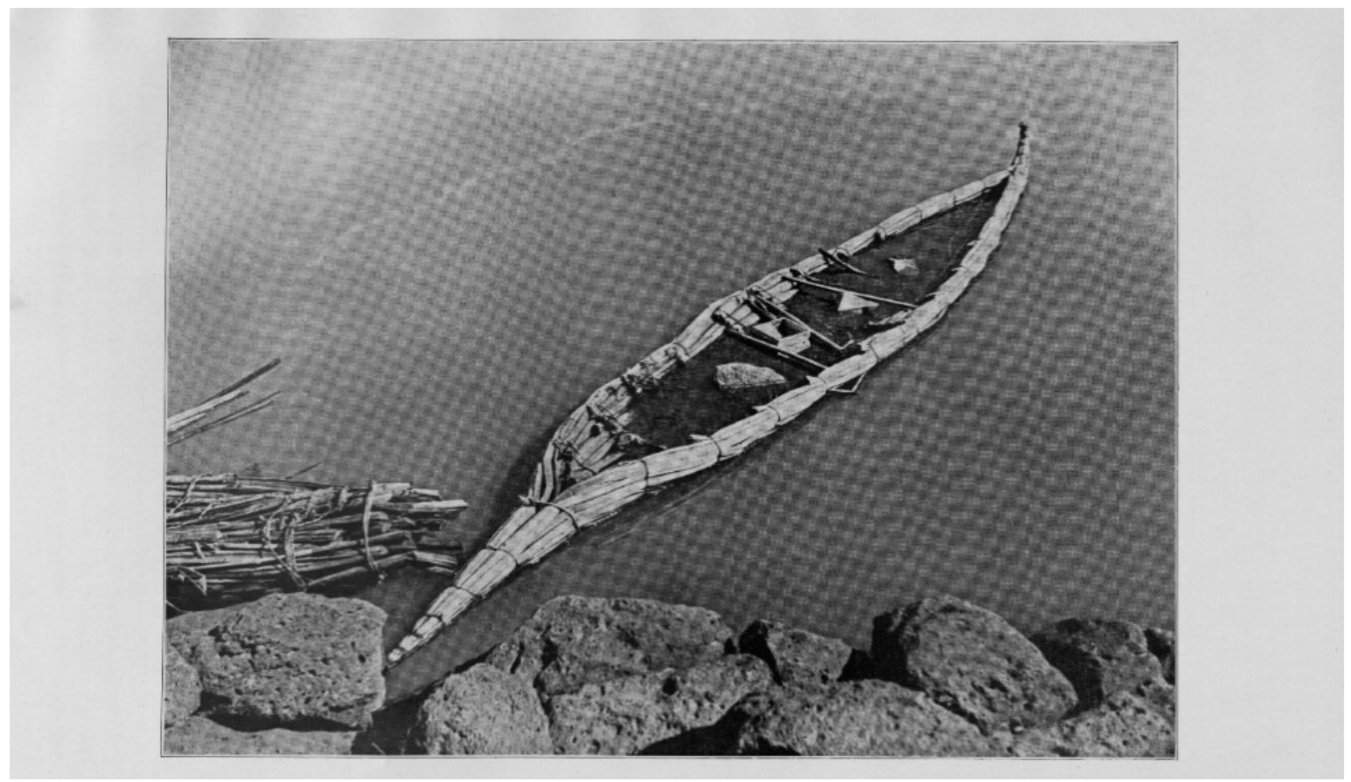

Figure 5. The photograph taken in 1920 shows a tank evaporimeter floated on a Tankua (a locally made tiny boat) on Ifwadda Lagoon nearby Lake Tana outlet. It was used by sinking the Tankua to about $5 \mathrm{~cm}$ and anchoring it with rocks to maintain temperature equality between inside and outside.

For over-lake evaporation depth estimation, Rientjes et al. [13] used a procedure that combined the Penman-combination equation developed by Maidment [48], using daily data from Bahir Dar meteorological station, and a satellite-based approach. They estimated the mean annual evaporation to be1563 mm for the period 1994-2003 (Table 2). Similarly, Wale et al. [14] used the same technique but from two meteorological stations (Table 1), and estimated $1690 \mathrm{~mm} /$ year. Kebede et al. [28] applied the Penman method by using long period monthly meteorological data (1960-1992) from only Bahir Dar station and estimated the over-lake evaporation to $1478 \mathrm{~mm}$ (Table 2). SMEC [26] and Mamo [30] estimated the evapotranspiration from land, and evaporation from open lake water using the Penman-Monteith and Penman methods, respectively, at a monthly time scale. They assumed that the marshy area surrounding the lake was open water from August to November, and dryland for the rest of the year. SMEC [26] estimated the over-lake mean annual evaporation to be $1697 \mathrm{~mm}$ while Mamo [30] estimated it to be $1544 \mathrm{~mm}$. Similar to Rientjes et al. [13] and Wale et al. [14], the Penman combination method was applied by Dessie et al. [12]. They used minimum and maximum temperature from six stations 
(mostly at the lakeshore), and only Bahir Dar station for sunshine hours, wind speed and relative humidity, and estimated the daily over-lake evaporation for the period 20122013. They found average annual evaporation of $1789 \mathrm{~mm}$ (Table 2). The estimation was higher than that determined by Rientjes et al. [13], Wale et al. [14], Kebede et al. [28], and Mamo [30] (Table 2), which could be due to the addition of data from many meteorological stations. This shows the significant variability of meteorological parameters over the lake. Underestimation of evaporation/evapotranspiration for coarser time scales compared to the fine (e.g., monthly over daily) had been noted by Bakundukize et al. [49]. However, this underestimate was not observed among the estimations made on Lake Tana (Table 2). This could be due to the consideration of meteorological data from different stations as well as the variability of the time series considered in the interpolation. Chebud and Melesse [42] estimated evapotranspiration using the Penman, the mass transfer (Meyer's deterministic), and the Thornthwaite methods. The Penman method (representing the energy budget approach) and Meyer's mass transfer approach, were applied for estimating the monthly lake evaporation (Table 2). The Thornthwaite method was used for the yearly lake evaporation and underestimated the evaporation from the lake. The energy budget and mass transfer methods show a significant seasonal pattern. From January to June, when buoyancy dominates the turbulent ET production, the energy budget method is more relevant. From June to October, when turbulent production dominates, the Meyer's mass transfer method becomes more pertinent [42], resulting in ET estimations higher by $20-300 \mathrm{~mm}$ compared to the Penman method. In general, the seasonal application of methods is suggested, instead of using solely one of them for all months.

Table 2. Lake evaporation estimations made by different authors (applying different methods) for different periods and time scales.

\begin{tabular}{|c|c|c|c|c|c|}
\hline Literature & Timescale & Data Period & Number of Stations & $\begin{array}{c}\text { Estimation Method } \\
\text { Applied }\end{array}$ & $\begin{array}{l}\text { Annual Over-Lake } \\
\text { Evaporation (mm) }\end{array}$ \\
\hline Grabham and Black [22] & monthly & 1920-1921 & $\begin{array}{l}\text { Direct measurements at } \\
\text { points and areal } \\
\text { extrapolation }\end{array}$ & $\begin{array}{l}\text { Direct measurements } \\
\text { using Piche and Tank } \\
\text { Evaporimeters }\end{array}$ & 1365 \\
\hline Wale et al. [14] & daily & 1992-2003 & $\begin{array}{l}2 \text { (Gondar and Bahir Dar } \\
\text { stations) }\end{array}$ & $\begin{array}{c}\text { Penman-combination } \\
\text { equation }\end{array}$ & 1690 \\
\hline Rientjes et al. [13] & daily & 1994-2003 & 1 (Bahir Dar station) & $\begin{array}{c}\text { Penman-combination } \\
\text { equation }\end{array}$ & 1563 \\
\hline Kebede et al. [28] & daily & 1960-1992 & 1 (Bahir Dar station) & Penman & 1478 \\
\hline \multirow{2}{*}{ SMEC [26] } & monthly & 1960-2005 & \multirow{2}{*}{$\begin{array}{c}2 \text { (Bahir Dar and Gondar } \\
\text { stations) }\end{array}$} & Penman & 1697 \\
\hline & monthly & 1960-1995 & & Energy balance method & 1657 \\
\hline Mamo [30] & monthly & 1995-2009 & 1 (Bahir Dar station) & Penman & 1544 \\
\hline Setegn et al. [33] & daily & 1978-2004 & $\begin{array}{c}\text { not explicitly mentioned } \\
\text { (probably Gondar and } \\
\text { Bahir Dar) }\end{array}$ & Hargreaves method & 1248 \\
\hline Dessie et al. [12] & daily & $2012-2013$ & $\begin{array}{l}6 \text { (but Wind speed, } \mathrm{RH}, \\
\text { and sunshine hours, only } \\
\text { from Bahir Dar) }\end{array}$ & $\begin{array}{l}\text { Penman-combination } \\
\text { method }\end{array}$ & 1789 \\
\hline \multirow{3}{*}{ Chebud and Melesse [42] } & monthly & \multirow{3}{*}{ 1960-2003 } & \multirow{3}{*}{$\begin{array}{l}1 \text { (Bahir Dar station) } \\
\text { aided by Satellite images, } \\
\text { and GHCN }\end{array}$} & Penman & 1458 \\
\hline & monthly & & & Meyer's mass transfer & 1543 \\
\hline & yearly & & & Thornwaite method & not reported \\
\hline
\end{tabular}

\subsection{River Water Inflows to Lake Tana}

The inflow of the main rivers has been estimated by different authors (Table 3). SMEC [26] used long-term meteorological and hydrological data and determined the annual flow in the Gilgel Abay River (which was about $994 \mathrm{~mm}$, which is $53 \%$ of the catchment's areal rainfall). A high total river discharge value was also measured for the Gumara river. However, for the adjacent Rib river catchment, they found low river 
discharge despite its receiving a similar annual rainfall amounts to the Gumara catchment. The Gumara catchment received about $80 \mathrm{~mm}$ more annual rainfall than the Rib, but its river discharge was higher by $400 \mathrm{~mm}$.

Table 3. Summarized annual estimations for river water inflows of Lake Tana by various authors. The model or estimation technique used, time scale, data period, the gauged areal coverage where the inflow data for model calibration and validation used are indicated.

\begin{tabular}{|c|c|c|c|c|c|c|c|}
\hline \multirow[b]{2}{*}{ Literature } & \multirow[b]{2}{*}{ Timescale } & \multirow[b]{2}{*}{ Data Period } & \multirow{2}{*}{$\begin{array}{l}\text { Ungauged Flow } \\
\text { Estimation Method }\end{array}$} & \multirow{2}{*}{$\begin{array}{l}\text { Type of Model } \\
\text { Applied }\end{array}$} & \multicolumn{3}{|c|}{ River Inflow } \\
\hline & & & & & $\begin{array}{l}\text { Gauged } \\
(\mathrm{mm})\end{array}$ & $\begin{array}{l}\text { Ungauged } \\
\text { (mm) }\end{array}$ & $\begin{array}{l}\text { Total } \\
(\mathrm{mm})\end{array}$ \\
\hline Wale et al. [14] & daily & 1992-2003 & $\begin{array}{l}\text { regionalization, spatial } \\
\text { proximity, and catchment } \\
\text { size comparison }\end{array}$ & HBV-96 & 1280 & 880 & 2160 \\
\hline $\begin{array}{l}\text { Rientjes et al. } \\
\text { [13] }\end{array}$ & daily & 1994-2003 & regionalization & HBV-96 & 1252 & 526 & 1778 \\
\hline Kebede et al. [28] & daily & 1960-1992 & gross runoff coefficient & Simple mass balance & 1082 & 80 & 1162 \\
\hline SMEC [26] & monthly & 1960-2005 & $\begin{array}{l}\text { multiplication factor } \\
\text { developed from lake } \\
\text { evaporation versus } \\
\text { gauged inflow amount }\end{array}$ & $\begin{array}{l}\text { simple mathematical } \\
\text { water balance } \\
\text { equation }\end{array}$ & 1622 & 497 & 2119 \\
\hline Mamo [30] & monthly & 1995-2009 & gross runoff coefficient & $\begin{array}{c}\text { hydrological } \\
\text { continuity equation } \\
\text { or chemical mass } \\
\text { balance }\end{array}$ & 1356 & 735 & 2091 \\
\hline Setegn et al. [33] & daily & 1978-2004 & Gross runoff coefficient & SWAT2005 & 1193 & 129 & 1322 \\
\hline Dessie et al. [12] & daily & 2012-2013 & $\begin{array}{l}\text { regionalization for hill } \\
\text { slope, and runoff } \\
\text { coefficient for floodplain }\end{array}$ & $\begin{array}{l}\text { Simple process-based } \\
\text { conceptual }\end{array}$ & 1807 & 394 & 2201 \\
\hline $\begin{array}{l}\text { Chebud and } \\
\text { Melesse [42] }\end{array}$ & monthly & 1960-2003 & ignored & $\begin{array}{l}\text { Simple mass balance } \\
\text { and MODFLOW }\end{array}$ & 1128 & $\begin{array}{c}\text { not } \\
\text { accounted }\end{array}$ & 1128 \\
\hline
\end{tabular}

Dessie et al. [11] analyzed runoff for Gilgel Abay and Upper Gumara catchments by developing a process-based hydrological model based on a simple water balance approach. Accordingly, about $65 \%$ of the total discharge for Gumara is from interflow (unsaturated soil reservoir). Surface runoff generates a lower fraction of total stream discharge (18-19\% for Gumara and 20\% for Gilgel Abay). Setegn et al. [33] applied SWAT for hydrological modeling of the Lake Tana Basin water balance for the period 1978-2004 (Table 3). The total simulated annual flows for Gilgel Abay, Megech, Gumara, and Rib were respectively, $900 \mathrm{~mm}, 265 \mathrm{~mm}, 1830 \mathrm{~mm}$, and $553 \mathrm{~mm}$. According to them, the model performed well for the rivers except for Megech catchment. They attributed the poor match for Megech as being due to an underestimation of rainfall and evapotranspiration (due to the low number of meteorological stations) and/or due to regulated flow by a dam constructed in the upper part of the basin. Dessie et al. [12] found that about $58 \%$ of the inflow to the lake was from the Gilgel Abay catchment, which covers $38 \%$ of the total lake basin area. The western and northern catchments of the lake were less important in terms of their contribution per surface area [12]. Dessie et al. [12] estimated the water balance terms of the Lake Tana Basin by considering the effect of the floodplain of the basin with two scenarios: 1) with an absence of the floodplain, and 2) with its presence (the real situation). They used data from thirteen river gauging stations which increased the gauged areal coverage from $42 \%$ in the previous studies to $60 \%$ (Figure 6 and Table 3). Three of the stations were in the floodplain of the major rivers (Gumara, Rib, and Megech). The runoff response for the hill and the floodplain areas were analyzed separately using separate gauge data set. Therefore, with floodplain buffering (with about $931 \mathrm{~km}^{2}$ of floodplain area being omitted), the total inflow from the rivers into the lake was $2349 \mathrm{~mm}$, while the estimate was $2201 \mathrm{~mm}$ in the realistic scenario. The difference between the two approaches indicates that an appreciable volume of river inflow to the lake, about $148 \mathrm{~mm}$ is abstracted 
within the floodplain which SMEC [26] roughly estimated at only $15 \mathrm{~mm}$. Rientjes et al. [13] used a Monte Carlo procedure for calibrating their HBV-96 water balance model using daily meteorological and streamflow data from 1994-2003. Their estimated streamflow was lower than the estimate made by Wale et al. [14] despite using the similar method and time-series data. This could be due to several reasons that relate to the use of the advanced model calibration procedure and the selection of a different set of physical catchment characteristics that used for regionalization.

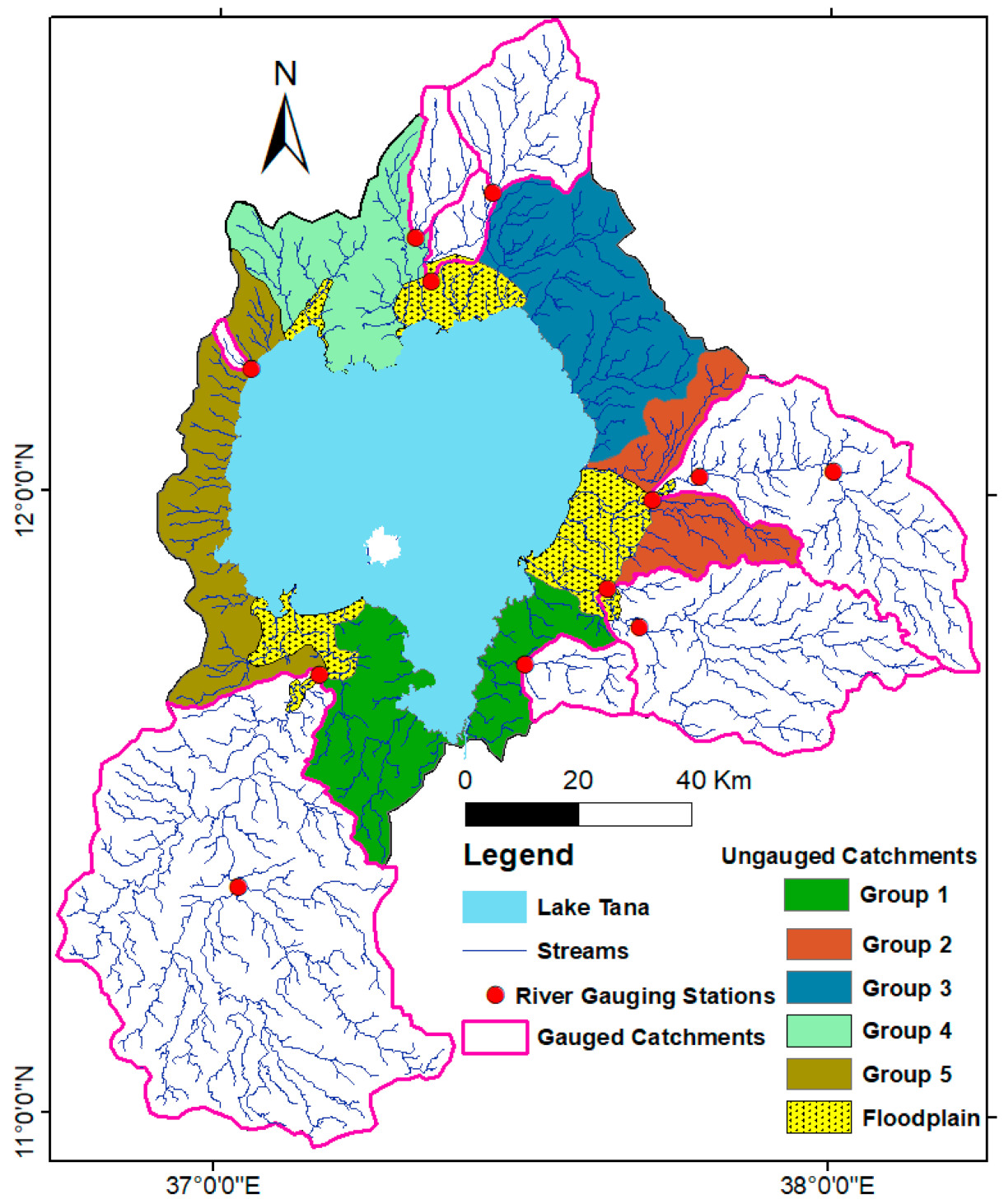

Figure 6. Map of Lake Tana Basin with the location of the floodplain, gauged and ungauged catchments modified after Dessie et al. [12]. According to Dessie et al. [12], runoff from the groups of ungauged catchments was predicted based on calibrated model parameters of observed runoff data from Gelda for Group 1, from Rib for Group 2, from Megech for Group 3, from Dirma for Group 4, and Dirma for Group 5. The selection of hydrological areas to transfer hydrological parameters is based on similarities in hydro-physical characteristics.

More than 40 rivers flow to Lake Tana [11-14], which makes gauging all of them difficult. As a result, different methods and procedures have been followed to estimate the ungauged river contribution in the water balance estimations, usually by regionalization techniques, i.e., transferring hydrological model parameters of gauged rivers to ungauged rivers (e.g., [13,42]), some by simply using lumped runoff coefficient values (runoff here refers total river discharge) adapted from regional literature (e.g., in [28,33]), 
and some others using both simple rainfall-runoff model and runoff coefficients together (e.g., [12]). Dessie et al. [12] used regionalization for hill slope parts (Figure 6), and a runoff coefficient for the floodplain from neighboring gauged catchments. SMEC [26] found that regionalization, between catchments that were supposed to have similar meteorological, physio(hydro)graphic, and anthropogenic factors was misleading because gauged catchments with similar characteristics have highly different runoff responses, e.g., Rib vs. Gumara and main Gilgel Abay vs. its sub-catchments, Koga and Kilti (Figure 1). As a result, they used a multiplication factor developed from relationships of lake evaporation versus gauged inflow amount. Similarly, Kim and Kaluarachchi [50] also noted the difficulty of transferring model parameters in the Upper Blue Nile River Basins. Kebede et al. [28] estimated ungauged runoff using the gross runoff coefficient of 0.22 (adapted from regional literature). Kebede et al. [18] applied an isotopic balance method $\left({ }^{18} \mathrm{O}\right.$ content of the water) to estimate the inflow contribution of ungauged catchments. The isotopic method is a different approach compared to physically-based hydrological models. Hence, their work was independent verification of other estimations made using regionalizing or an assumed runoff coefficient. The isotopic method of Kebede et al. [18], however, had uncertainties estimations of some sensitive parameters in the isotopic balance equation. On average, they found about $16.4 \%$ (113 mm/year) of the total river inflow to the lake is being contributed by ungauged catchments, in between the estimations by Kebede et al. [28] and SMEC [26] which were $7 \%$ and $25 \%$, respectively. The $16.8 \%$ estimation was comparable to the value found by Rientjes et al. [13], using regionalization (Table 3). The ungauged river inflow contribution by Kebede et al. [18] and Dessie et al. [12], are almost equal, $538 \mathrm{~mm}$ and $530 \mathrm{~mm}$, respectively, despite each of the studies applied completely different techniques. Wale et al. [14] estimated the discharge contribution from ungauged catchments using daily meteorological and gauged river data of 1995-2001. They used regionalization, spatial proximity, and catchment size comparison method for regionalizing calibrated HBV model parameters (Table 3). Accordingly, they estimated $42 \%$ using the regionalization method, $47 \%$ for the spatial proximity method, and $46 \%$ for the catchment size comparison method. The ungauged catchments inflow contribution calculated by Wale et al. [14] is six and two times of the previous estimations made by Kebede et al. [28] and SMEC [26], respectively. According to Rientjes et al [13], about $29.5 \%$ of the inflow to Lake Tana is from ungauged systems while the area they cover is nearly $62 \%$. Mamo [30] estimated ungauged catchments, as a product of estimated areal rainfall with a runoff coefficient of 0.314 .

The total discharge of the rivers is mainly contributed both by surface runoff and groundwater. Different authors had tried to separate the groundwater component from the other river discharge components (surface runoff and interflow). According to Dessie et al. [11], 44-48\% of Gilgel Abay river discharge was from groundwater. Setegn et al. [33] estimated that the groundwater accounts for about $50 \%$ of the total river inflow to the lake. This was similar to the estimation made by Abiy et al. [27]. Abiy et al. [27] used the SWAT model to obtain groundwater contributions of $718 \mathrm{~mm} /$ year for Gilgel Abay, $414 \mathrm{~mm} /$ year for Gumara, $451 \mathrm{~mm} /$ year for Rib, and $350 \mathrm{~mm} /$ year for Megech. This accounts for about $60 \%$ of the total annual river inflow to the Lake Tana water body, which is more or less similar to the findings of SMEC [26]. SMEC [31], and later Dessie et al. [11,12] concluded that there is significant groundwater contribution to both Gilgel Abay and Gumara rivers flow while only little for Megech and Rib. The differences could be explained by the highly permeable Quaternary basaltic aquifer seen on both of the former catchments which are absent on the latter. Setegn et al. [33] had also estimated the groundwater contribution of the main rivers: $54 \%$ for Gilgel Abay $(486 \mathrm{~mm}), 60 \%$ for Megech $(159 \mathrm{~mm}), 64 \%$ for Gumara $(1171 \mathrm{~mm})$, and 65\% for Rib $(360 \mathrm{~mm})$. Except for Gumara the groundwater contribution estimation by Setegn et al. [33] is lower than the estimations by Abiy et al. [27]. The groundwater contributions for the Rib and Megech rivers as estimated by SMEC [26] and Dessie et al. [15] were considered very small. 


\subsection{Lake Water Outflow Estimation}

Historically, measurement of the Upper Blue Nile discharge at the outlet of Lake Tana was made for the first time by Grabham and Black [22] at regular times in the years of 1920-1923. It was estimated to $23 \mathrm{~mm}$ /year, which is close to recent estimations which had used better data sets. River discharge data source for all of the water balance studies which used historical data back in time to 1960 or more recent data were all obtained from the Ministry of Water Resources (MoWR) (e.g., in [12-14,26,33,42]). However, there was some confusion with supplied data, and hence SMEC [26] checked the reliability of the data by comparing the average flow velocity multiplied by the wetted cross-section with the discharge on the summary sheets and found deviations on a few of the measurements. This could be due to problems with the rating curve and/or possible reference point variations for river stage measurement at different times. From 1960 to 1995, the lake water was flowing naturally. However, in 1996 a weir at the outlet was built, which raised the lake water permanently [26]. The outflow from the lake is controlled manually by gates at the outlet to the Blue Nile and a tunnel to the hydropower outlet (Tana-Beles) since 2010. Due to the diversion of lake water to the hydropower plant, lake outflow to the Blue Nile river dropped to $157 \mathrm{~mm}$ /year during the years 2012 and 2013, in contrast to its average annual outflow of $278 \mathrm{~mm} /$ year before May 2010 [12]. Azeze et al. [51] applied a stochastic modeling technique (a first-order autoregressive model) and found it effectively simulated the lake outflow.

In general, the lake water outflow estimates by Kebede et al. [28] and SMEC [26] were relatively low, compared with other studies (Table 4). This could be due to a problem of an old lake stage-discharge rating curve, which could possibly be erroneous because in both studies data before 1996 were used. The other studies had more or less similar results. The annual values calculated by Dessie et al. [12] and Chebud and Melesse [42] are higher than the others (Table 4). In the former, this could have been due to more water abstraction, since the study used the outflow data after the start of water conveyance to the Beles Basin, while in the latter, this could have been possible due to a uniform surface area assumption in the rating curve development.

\subsection{Lake Level Simulation}

Lake level had been simulated by all the authors who estimated the water balance of the lake with different timescales (e.g., in [12,14,33,42]). For simulating the lake level, a simple water balance model is applied and further compared with the observed lake levels [26]. The lake bathymetry is needed to estimate the change in lake-stage with changes in volume. Different Lake bathymetry surveys are documented in Wale et al. [14]. The first detailed survey was carried out by Pietrangeli [52], and later by Kaba [53] with sonar and GPS (cited in $[12,14,26,28]$ ). A detailed and wide study of the bathymetric survey of Lake Tana was later conducted by Omega Development Service Plc in 2012, financed by the Ethiopian Ministry of Water, Irrigation, and Energy [12].

The earliest records of the Lake Tana levels started in 1920 [22]. However, data recorded since 1960 are more reliable. The annual lake level fluctuations are about $1.6 \mathrm{~m}$, reaching a maximum around September and a minimum around June [12,14]. Simulated versus observed lake levels indicated a good match, where climatic seasonality with clear dry and wet periods was well presented in the simulated lake level values [13]. In the study by Rientjes et al. [13], large deviations were observed specifically during the first few and last few years of the simulation period 1994-2003, for reasons that could not be identified and related to any of the water balance terms. 


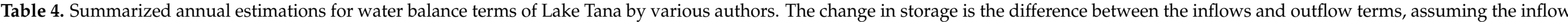
positive and the outflow negative. The percentages are individual terms per total inflows or outflows.

\begin{tabular}{|c|c|c|c|c|c|c|c|c|c|}
\hline Literature & $\begin{array}{l}\text { Time } \\
\text { Scale }\end{array}$ & $\begin{array}{c}\text { Over-Lake } \\
\text { Precipitation } \\
\left(10^{6} \mathrm{~m}^{3}\right)\end{array}$ & $\begin{array}{c}\text { Gauged River } \\
\text { Inflow } \\
\left(10^{6} \mathrm{~m}^{3}\right)\end{array}$ & $\begin{array}{l}\text { Ungauged } \\
\text { River Inflow } \\
\left(10^{6} \mathrm{~m}^{3}\right)\end{array}$ & $\begin{array}{c}\text { Lake } \\
\text { Evaporation } \\
\left(10^{6} \mathrm{~m}^{3}\right)\end{array}$ & $\begin{array}{l}\text { River Outflow } \\
\qquad\left(10^{6} \mathrm{~m}^{3}\right)\end{array}$ & $\begin{array}{l}\text { Groundwater } \\
\text { Inflow/Outflow } \\
\left(10^{6} \mathrm{~m}^{3}\right)\end{array}$ & $\begin{array}{c}\text { Irrigation } \\
\text { Abstraction from } \\
\text { Ungauged Rivers } \\
\left(10^{6} \mathrm{~m}^{3}\right)\end{array}$ & $\begin{array}{c}\text { Closure Term } \\
\left(10^{6} \mathrm{~m}^{3}\right)\end{array}$ \\
\hline Wale et al. [14] & daily & $3784(36.1 \%)$ & $3970(37.9 \%)$ & $2729(26 \%)$ & $5242(52.7 \%)$ & $471447.3 \%)$ & 0 & 0 & $+527(5 \%)$ \\
\hline $\begin{array}{c}\text { Rientjes et al. } \\
\text { [13] }\end{array}$ & daily & $4104(43.1 \%)$ & $3821(40.1 \%)$ & $1605(16.8 \%)$ & $4762(51.4 \%)$ & $4502(48.6 \%)$ & 0 & 0 & $+260(2.7 \%)$ \\
\hline $\begin{array}{c}\text { Kebede et al. } \\
\text { [28] }\end{array}$ & monthly & $4431(55.5 \%)$ & $3300(41.4 \%)$ & $\begin{array}{l}<248(3.1 \%) \\
\text { Later to } 1698 \text { by } \\
\text { Kebede et al. } \\
\text { [18] isotopic } \\
\text { method }\end{array}$ & $4513(55.3 \%)$ & 3399 (41.7\%) & $<248(3 \%)$ & & $+68(0.8 \%)$ \\
\hline SMEC [26] & monthly & $3816(43.4 \%)$ & $3444(39.1 \%)$ & 1542 (17.5\%) & $5073(57.5 \%)$ & $3753(42.5 \%)$ & $\begin{array}{c}0 \\
955(9.2 \%)\end{array}$ & 0 & $-24(0.3 \%)$ \\
\hline Mamo [30] & monthly & $4016(37.9 \%)$ & 4207 (39.7\%) & $2278(21.5 \%)$ & $4720(45.3 \%)$ & $4733(45.5 \%)$ & $\begin{array}{l}\text { (outflow) } \\
93(0.9 \%) \\
\text { (inflow) }\end{array}$ & 0 & $+186(1.8 \%)$ \\
\hline Setegn et al. [33] & daily & $4300(51.2 \%)$ & 3700 (44\%) & $400(4.8 \%)$ & $3900(49.4 \%)$ & $4000(50.6 \%)$ & 0 & 0 & $+500(6 \%)$ \\
\hline Dessie et al. [12] & daily & $4129(37.7 \%)$ & $5608(51.2 \%)$ & $1223(11.1 \%)$ & $5547(51.8 \%)$ & $5023(46.9 \%)$ & 0 & $134(1.3 \%)$ & $+256(2.3 \%)$ \\
\hline
\end{tabular}


However, Chebud and Melesse [42] identified that the final deviation was due to the installation of additional gates at the Chara Chara weir in 2001, which had led to a sudden drop. Chebud and Melesse [42] employed three stochastic methods (perturbations approach, Monte Carlo methods, and wavelet analysis) for lake level and volume simulation to capture historically well-known events of drawdown and rise of the lake that had happened in the last 44 years (1960 to 2004), and which were not identified by simple water balance approach of inflow, outflow, and storage (e.g., in [13,14,28,33]). The stochastic simulations predicted the lake stage level of the 1972, 1984, and 2002/2003 historical droughts by $99 \%$ accuracy. Kebede et al. [28] found that, unlike other East African lakes whose level significantly varies for small rainfall changes, Lake Tana level is less sensitive for rainfall variations which is a typical characteristic of lakes with significant outflow. Dessie et al. [12] simulated the lake level reasonably (with $\mathrm{R}^{2}=0.95$ between observed and simulated values). Alemayehu et al. [17] applied the WEAP (Water Evaluation and Planning) model and assessed the impact of the then planned water resources development plans which are now partly completed and operating in the Lake Tana Basin. According to them, these projects will bring about an annual lake water level drop of $0.44 \mathrm{~m}$.

\subsection{Groundwater Inflow to/Outflow from Lake Tana}

Interaction of groundwater and lake water, as well as groundwater flow to and from Lake Tana, is assumed negligible or very little in most of the water balance studies (e.g., in $[12-14,28,33,42])$. Using the stable $1^{8} \mathrm{O}$ and ${ }^{2} \mathrm{H}$ isotope method, Mamo [30] agreed with negligible interaction between Lake Tana and the groundwater beneath the lake. Similarly, Kebede et al. [18] found little interaction. Unlike the ${ }^{18} \mathrm{O}$ and ${ }^{2} \mathrm{H}$ enrichment of the lake water, the shallow groundwater in the floodplain shows depletion, showing less linkage and little or no interaction of the waters [18]. The annual floodplain abstraction of the river inflows calculated by Kebede et al. [18], and by Dessie et al. [12], using the stable isotopic and water balance approaches, is $454 \times 10^{6} \mathrm{~m}^{3}$ and $420 \times 10^{6} \mathrm{~m}^{3}$, respectively. The isotopic linkage between lake water and groundwater immediately downstream in the southern natural outlet was compared by Kebede et al. [18]. They concluded that there is no evidence for subsurface groundwater leakage out of the basin. Later Mamo [30], applying a similar method, came up with a contrasting conclusion that there is a measurable groundwater outflow to Blue Nile Basin. Any groundwater outflow towards the Beles basin in the southwestern part (Figure 1), showing strong topographical and hydrogeological suitability, was not dealt with by Kebede et al. [18]; later, Mamo [30] found a significant outflow amount (Table 4). The presence of a deep lineament network in the western margin towards the adjacent Beles basin, where an important outflow amount was estimated, gives good geological evidence for the high groundwater leakage [30]. Similar to Kebede et al. [28], SMEC [26] assumed insignificant lake water-groundwater interaction with lake bottom as well as surrounding aquifers, owing to the thick clay and silt deposit on most of the lake floor, and the very low hydraulic gradient between the lake and the groundwater aquifers near to the lake. This low hydraulic gradient, and hence low groundwater inflow to the lake from the shallow lacustrine aquifer was also supported by Enku et al. [54] through their study conducted on the Gumara floodplain (Figure 6). Chebud and Melesse [42] estimated the groundwater inflow using a simple MODFLOW model at 3\% of the total river water discharge. This estimate was in line with the assumption of less than $7 \%$ groundwater contribution by Kebede et al. [28].

\subsection{Irrigation Water Amount from the Ungauged Rivers}

Irrigation using a surface motor pump from different rivers and hand-dug wells is being commonly practiced in the Lake Tana basin. Dams and diversions have also been built, and a significant amount of agricultural land is being irrigated. Irrigation water from gauged rivers is considered in the balance calculation since the river gauging stations measure inflow left after irrigation. However, those from the ungauged are not considered in the water balance calculations of the lake (Table 4). Dessie et al. [12] estimated the 
irrigation water amount abstracted from the ungauged catchments was to $133 \times 10^{6} \mathrm{~m}^{3}$ per annum, which could cause an annual lake level drop of $43 \mathrm{~mm}$. According to Alemayehu et al. [17], when the complete irrigation development plan in the whole basin (irrigation both in the gauged and ungauged catchments) is realized, roughly $3600 \times 10^{6} \mathrm{~m}^{3}$ per year of water will be consumed.

Though it is difficult to evaluate which one of the studies best estimated the different water balance terms, Dessie et al. [12] seemed better estimated due to the following reasons. (1) they have used the maximum number of rainfall stations (34 stations) for the areal interpolation of the rainfall amount. (2) they treated the hilly and the floodplain part differently by installing river gauging stations at the foothill, and in the middle of the floodplains, respectively. This is a good approach as runoff response would be different for the two topographies (3) their river inflow estimation is using river flow data by increasing the gauged part of the study area from about $40 \%$ to $60 \%$. (4) most importantly, their river flow data is their own. They established the stations and developed rating curves. Besides, the river water level is collected with a very fine time scale (10-15 $\mathrm{min}$ ) using automatic data recorders, which the others used data recorded manually at a daily scale. Considering the highly changing river morphology where stations are established by the Ministry of Water Resources, regular updating of the rating curve would have been important, and hence possible calculation errors would be significant in the river flow data used by the other authors that Dessie et al. [12] had not used. (5) irrigation consumption had been for the first time (Table 4). Having these all, the estimated value of the different water balance components by Dessie et al. [12] can be taken as the best estimates. However, they had not invested anything in the groundwater component, and hence, the groundwater inflow and outflow were assumed $0 \mathrm{~mm}$ like many of the other studies.

\subsection{Summary of the Lake Water Balance Estimations and Closure Terms}

Different authors presented estimations of the water balance components of Lake Tana (Table 4). The time scale used for measuring and equating the different budget components and the errors incorporated in the balance of the inflow and outflow terms is also indicated (Table 4). Though the errors of estimating the inflow and outflow terms would have been balanced by themselves, the closure term might give some clue about the effectiveness of the water balance calculation of each study. The water balance estimations by Dessie et al. [12] had closure error of $+742 \times 10^{6} \mathrm{~m}^{3}$ and $+256 \times 10^{6} \mathrm{~m}^{3}$, respectively, for floodplain absent and with floodplain considered scenarios, showing that the floodplain has a significant effect on the water balance estimation. According to Setegn et al. [33], the analysis of the Lake Tana water balance has shown that there is an annual surplus ( $6 \%$ of the inflow) of water (Table 4). In the study of Chebud and Melesse [42], there is a $23.3 \%$ inflow deficit compared to the outflow. They ascribed the imbalance to the ruling out of runoff contributions from the floodplain (downstream of the gauging stations), regional groundwater flow, errors of measurements, and calculations. However, Dessie et al. [12] concluded that the floodplain consumes rather than contributing to the runoff. In the view of this review paper, the deficit amount by Chebud and Melesse [42] is due to the disregarding of the inflow from the ungauged rivers, from which most authors (e.g., in $[13,14,18,26,30]$ ) estimated comparable (even more) results (Table 4). The closure error in the study of Wale et al. [14] is reported to $-527 \times 10^{6} \mathrm{~m}^{3}$ in the paper (Table 4) which is in fact $+527 \times 10^{6} \mathrm{~m}^{3}$ when we recalculated. In general, higher total inflow terms (up to $6 \%$ ) compared to outflow (Table 4) may support the hypothesis of lake water outflow via groundwater to mainly the adjacent Beles basin.

\section{Hydrogeological Studies in Lake Tana Basin and Related Volcanic Ethiopian Plateau Aquifer System}

A relatively small number of groundwater studies exist compared to surface water studies for Lake Tana Basin in particular and Upper Blue Nile Basin in general. These are studies on physical hydrogeology (e.g., [18,30]), hydrogeochemistry (e.g., [18,29]) and groundwater isotopes (e.g., in $[18,29,30,55])$. Groundwater in the Upper Blue Nile Basin 
is the main water source for large cities and towns [31]. According to Alemayehu and Kebede [31], the hilly and mountainous topography of the basin causes the recharge mechanism to be more mountain-front recharge type where the groundwater moves into the alluvial deposits and fractured rocks, and incised topography intercepts the recharge mound generated from hillsides. The stream valleys and lowlands are the major discharge areas that are usually characterized either by wetlands or springs or both $[29,31]$. Lake Tana Basin is generally underlain by three hydrostratigraphic units: the Tertiary volcanics, the Quaternary basalts, and the early Quaternary to recent alluvio-lacustrine sediments $[41,56]$. Generally, the Tertiary formation is less productive than the Quaternary basalts and alluvial deposits [41]. There are no drilling data available to confirm the existence of the Mesozoic sedimentary rocks in the study area as an aquifer [56]. Nevertheless, Hautot [57] suggested that possibly there are Mesozoic sedimentary rocks (having a thickness of about 1.5-2 km) beneath the basaltic sequence.

\subsection{Aquifer Characterization and Associated Physical Hydrogeological Studies}

SOGREAH [58] applied four different geophysical techniques and mapped the subsurface geology of Lake Tana Basin beneath the flat floodplain area. Two geophysical units were identified in the floodplain. The upper unit with alternating layers of fine and coarse alluvial deposits and volcanic formations underlain by alternating layers of massive basalts, weathered and/or fractured volcanic formations. Fine sediments have been found closer to Lake Tana and at relatively shallow depth [58], correspond to lacustrine deposits. This is in contrast with most of the previous assumptions in the other hydrogeological studies (e.g., $[18,19,30])$, which assumed the lacustrine deposit to be thick and covering the whole floodplain area. In the geophysical interpretation of SOGREAH [58], the underlying volcanic unit, lateral and vertical heterogeneity in weathering and fracturing was commonly detected and can highly affect the groundwater potential. This volcanic unit was also identified by Kebede et al. [18] as the main aquifer in the floodplain. A similar survey in the northeast and northern plain area determined similar sub-surface geology. Besides, a number of faults trending north-south have been identified in all of the survey areas, which can have more potential for groundwater [58]. Many faults have been encountered especially in the Kola Diba floodplain (Figures 3 and 6), which is currently a well field comprising more than 15 deep wells and supplying Gondar and Kola Diba towns. SOGREAH [58] also applied similar geophysical techniques on the southern part of the basin to determine the Quaternary rock depth and hydrogeological characteristics, and to characterize the aquifer of high discharge springs. The upper highly permeable Quaternary vesicular basaltic lava flow has a depth of $10 \mathrm{~m}$ but reaches $20 \mathrm{~m}$ near the center where the springs are located, indicating the presence of an old topographical depression underlain by massive rhyolitic rocks in the spring area. The emergence of the high discharge springs could be due to the depression and the presence of impervious rhyolitic rock underneath. Nigate et al. [29] confirmed that the springs are chemically less evolved, and not deep circulating, and the high discharge is due to the highly permeable, highly fractured Quaternary basalts.

A thick sequence of basaltic lava flows [39] overlying the Mesozoic sedimentary rocks are separated by numerous layers of paleosols, which are perching and produce a multi-layer aquifer system in the basin. They are causing the emergence of contact and fracture-type springs, that are common on the upper hilly part of the plateau [31]. On some of the volcanic ridges, Alemayehu and Kebede [31] noted over eighteen basaltic flow layers. These multi-flow basaltic layers can cause more percolation time of the water in the unsaturated zone which results in a delay of groundwater recharge. There are paleosols between the lava flows which can act as aquitards and produce perched aquifers, that are commonly producing mountain-front springs.

The geological structures and geomorphology control both the flow system and the occurrence of groundwater in the volcanic province of the Ethiopian plateau [59]. This geological and geomorphological variability across the volcanic rock terrain can also be explained by the highly changing recharge rate. Ayenew et al. [59] noted that there are 
transmissive rocks and high recharge rates in some mountain-front aquifers. However, the groundwater storage is low owing to the fast release of the stored water into the adjoining plains through large open fractures. The highest infiltration is occurring in the Quaternary basalts (Figure 3), which are characterized by high transmissivity (100$200 \mathrm{~m}^{2}$ / day) compared to the relatively low transmissive basalts of Tertiary volcanic rock formation [28,31]. Studies by Kebede et al. [19], Ayenew et al. [59], Demlie et al. [60], and Alemayehu et al. [61] identified a deep aquifer system having long flow paths, and shallow aquifers discharging locally. Felsic rock ridges, volcanic centers, and dikes act as barriers to the groundwater circulation in the plateau part of the Awash basin [62]. According to Kebede et al. [18], they are one of the reasons for blocking deep groundwater flow paths and the emergence of high TDS spring waters in the Tana Basin. In addition, Alemayehu and Kebede [31] also noted high compartmentalization of the volcanic aquifers in the Lake Tana Basin by more recent faults and dike formations. Hence, different continuous aquifers are intersected and result in the appearance of artesian and mineralized groundwater from a deep aquifer system through springs and boreholes. The water level map shows that groundwater joins into Lake Tana from all directions and generally reflects surface water flow direction [63]. High hydraulic heads occur in the highlands, and groundwater flows under a steep hydraulic gradient towards Lake Tana, with the gradient then flattening on the floodplains adjacent to the lake [63] (Figure 7).

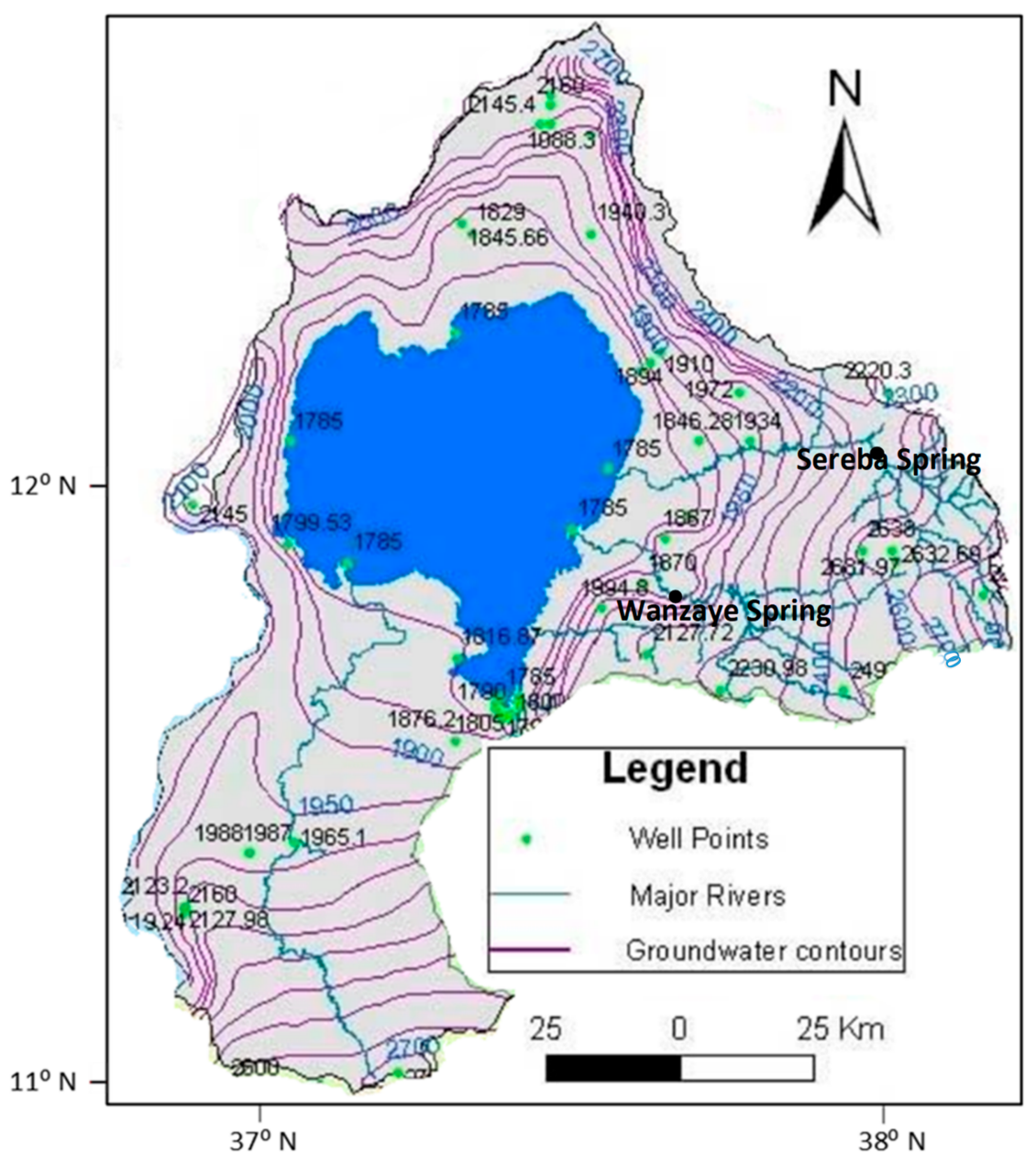

Figure 7. Groundwater head distribution in the Lake Tana Basin modified after Kebede et al. [63,64]. The hydraulic head values of the well points and some the contour are shown. The contour interval is $100 \mathrm{~m}$. They are concentrated on the highlands and relatively far apart in the plain part, showing the high gradient in the highland, and the low in the lowlands. 


\subsection{Groundwater Recharge and Surface-Groundwater Interaction Studies}

Values of 284, 285, and $196 \mathrm{~mm}$ /year were estimated as average groundwater recharge based on chloride mass balance (CMB), soil moisture balance (SMB), and baseflow separation techniques, respectively, for the whole of Tana Basin [30] (Table 5). The similarity of estimated values by the first two methods enabled the authors to conclude that the average value of $\mathrm{CMB}$ and $\mathrm{SMB}$ (i.e., $285 \mathrm{~mm}$ /year) represents the annual groundwater recharge, accounting for $20 \%$ of the average basin rainfall. Getenet [43] and Van Landtschoote [64] estimated groundwater recharge using $\mathrm{CMB}, \mathrm{SMB}$, water table fluctuation (WTF), and baseflow separation for the Rib and Gumara river catchments, respectively (Table 5). The recharge estimated in the flat, low-lying, extensive floodplain of Gumara (Figure 6) by Van Landtschoote [64] using the WTF method was about $105 \mathrm{~mm}$ (quite below the average range of 250 to $320 \mathrm{~mm} /$ year for the whole catchment). Similarly, Getenet [25] calculated the recharge in the floodplain part of Rib catchment using the WTF and SMB methods and found annual values of $98 \mathrm{~mm}$ and $124 \mathrm{~mm}$, respectively. These estimates of around $105 \mathrm{~mm}$ were in contradiction with the one determined by Enku et al. [54] using a similar method (Table 5). Enku et al. [54] estimated a groundwater recharge rate of $850 \mathrm{~mm}$ Yenehun et al. [65] applied different methods to estimate recharge on the upper part of Gilgel Abay catchment. They estimated $431 \mathrm{~mm}, 477 \mathrm{~mm}$, and $462 \mathrm{~mm}$, as mean annual recharge values using the $\mathrm{SMB}$, the $\mathrm{CMB}$, and the WetSpass (spatially distributed water balance model), respectively. They had also applied the WTF method, and calculated recharge values ranging from $157 \mathrm{~mm}$ to $760 \mathrm{~mm}$. Walker et al. [66] calculated the natural groundwater recharge using nine different methods in the shallow aquifers of Dangila area (upper part of Gilgel Abay catchment). In general, they found recharge ranging from 45 to $814 \mathrm{~mm} /$ year. However, the mean actual recharge amount has been estimated to range from $280-430 \mathrm{~mm}$. The SMB method overestimates while the WTF method strongly varies from place to place (higher on steeply sloping aquifers and lower on the flat lowlands) [64]. Generally, groundwater recharge is found storage controlled on the flat floodplain areas, and rainfall controlled on the highland areas [65,67]. Abiy et al. [27] estimated a recharge of 414 and $451 \mathrm{~mm} /$ year, respectively, for Gumara and Rib river catchments (excluding the lower floodplain), which could be overestimated. This could be due to assigning high values for model parameters pertinent to groundwater flow in the applied SWAT model. Comparison of SWAT applications for hydrological modeling on the same or similar case study but by different authors and/or model versions resulted in very different results in the upper Blue Nile Basin [67], owing to the representation challenges of the distributed processes and parameters, especially the land use. Beyene et al. [68] calculated the recharge from the return flow of flood irrigation water in the floodplain of Gumara river at traditional farmer-managed flood irrigation field using the WTF method. They found about $34-46 \%$ of the applied irrigation water is recharging the groundwater. Variation of the texture (mostly clay loam to sandy loam) and structure (granular and blocky) of the soil, is the reason for the variation of recharge across the study area. In general, as Yenehun et al. [65] evaluated, the water balance models such as the SMB and the WetSpass are appropriate methods in the highland area aquifers including sloping mountain-front aquifers, while water level measurement-based methods like WTF are preferred for storage controlled flat floodplain aquifers 
Table 5. Summarized groundwater recharge values estimated either on the whole Tana basin or on its catchments using different techniques.

\begin{tabular}{|c|c|c|c|}
\hline Literature & $\begin{array}{l}\text { Estimation Method } \\
\text { Applied }\end{array}$ & $\begin{array}{l}\text { Estimated Average Annual } \\
\text { Groundwater Recharge (mm) }\end{array}$ & Area of Application \\
\hline \multirow{3}{*}{ Mamo [30] } & SMB & 285 & \multirow{3}{*}{ Whole Tana Basin } \\
\hline & $\mathrm{CMB}$ & 284 & \\
\hline & Baseflow separation & 196 & \\
\hline \multirow{4}{*}{ Getenet [25] } & SMB & 365 & \multirow{4}{*}{$\begin{array}{c}\text { Whole Rib catchment; } \\
\text { WTF = 97.6 mm and SMB = } \\
123.5 \mathrm{~mm} \text { on the Rib } \\
\text { floodplain area }\end{array}$} \\
\hline & CMB & 154 & \\
\hline & Baseflow separation & 57 & \\
\hline & WTF & 189 & \\
\hline \multirow{4}{*}{ Van Landtschoote [64] } & SMB & $\begin{array}{l}\text { Ranging from } 235 \text { (for highland) to } \\
\qquad 320 \text { (central) }\end{array}$ & \multirow{3}{*}{ Gumara catchment } \\
\hline & $\mathrm{CMB}$ & $\begin{array}{l}\text { Ineffective (high } \mathrm{Cl} \text { - variation due } \\
\text { to pollution) }\end{array}$ & \\
\hline & Baseflow separation & 142 & \\
\hline & WTF & Ranging from 250 to 320 & $\begin{array}{l}\text { about } 105 \mathrm{~mm} \text { for the Gumara } \\
\text { floodplain area }\end{array}$ \\
\hline \multirow{2}{*}{ Abiy et al. [27] } & \multirow{2}{*}{ SWAT model } & 414 & Gumara catchment \\
\hline & & 451 & Rib catchment \\
\hline Enku et al. [54] & A simple water balance & 850 & Gumara floodplain \\
\hline \multirow{4}{*}{ Yenehun et al. [65] } & SMB & 431 & \multirow{4}{*}{$\begin{array}{l}\text { Upper part of Gilgel Abay } \\
\text { catchment }\end{array}$} \\
\hline & $\mathrm{CMB}$ & 477 & \\
\hline & WTF & 430 & \\
\hline & WetSpass & 462 & \\
\hline
\end{tabular}

Enku et al. [54] studied the shallow groundwater aquifer on the eastern floodplain of Lake Tana Basin using groundwater level monitoring data distributed all over the plain. They concluded that the groundwater is always (year-round) flowing towards the lake but with an insignificant rate owing to a very small hydraulic gradient and low hydraulic conductivity. Accordingly, they concluded that the lateral groundwater drain is very low and unimportant, and the groundwater level fluctuation is only in response to evapotranspiration. The estimated average annual evapotranspiration from the groundwater ranges from $850 \mathrm{~mm}$ to $1000 \mathrm{~mm}$ for different estimation approaches. The water level reaches the surface usually in the first week of August, where the recharge stops due to the unavailability of aquifer storage. They assumed the recharge is equal to the evapotranspiration of the dry period (based on a simple water balance assumption) and estimated the annual recharge to be $850 \mathrm{~mm}$. However, compared to the $1360 \mathrm{~mm} /$ year total annual rainfall amount in the floodplain, and the aquifers full recharging scenario in the first week of August [54], the evapotranspiration from the groundwater and then the recharge looked highly overestimated.

The high variation of the estimated values by different authors (Table 5) could show the strong spatial variability of recharge in the basin. Alternatively, the different authors used many different important assumptions that might bring significant errors. Fore example, the underestimation by baseflow separation could be due to deep aquifer percolations that have not been captured by the river discharge measurements which Mamo [30] also noted.

The groundwater flow to streams accounts for about $68.7 \%$ of the average basin groundwater recharge, while the remaining $31.3 \%$ is recharging the deep volcanic aquifer which does not return to streams or rivers [30]. According to Mamo [30], the water 
that recharges shallow aquifers returns to the local rivers and sustains the river flow (Figure 8a,b). Similarly, a significant baseflow amount was estimated by Setegn et al. [33], and particularly for Gumara and Gilgel Abay by Dessie et al. [11] and Kebede et al. [28]. Similar to Mamo [30], Van Landtschoote [64] identified two different flow systems; the shallow and deep systems. Water in the shallow is subjected to a shorter travel distance and appears at the surface as springs or contributes to river valleys, while the deeper flow travels regionally (Figure 8a). This deep groundwater converges in the lower floodplain part of the catchment and flows further towards Lake Tana. Deeper groundwater discharge directly to Lake Tana and the floodplain and shallow groundwater discharge to local valleys from upstream recharge areas in the northern and southern periphery of the Rib river catchment had also been noted by Enku et al. [25,30] (Figure 8b). Similar results by Alemayehu et al. [61], Ayenew et al. [59], Demlie et al. [58,60], and Kebede et al. [19] were also noted for the Ethiopian plateau volcanic aquifer including the Lake Tana Basin. Chebud and Melesse [42] applied MODFLOW on the floodplain of Gumara catchment and observed that the hydraulic head distribution for the dry season is from the rivers towards the groundwater system in the floodplain. According to Chebud and Melesse [42], about $160 \times 10^{6} \mathrm{~m}^{3}$ /year baseflow of the rivers recharges the floodplain aquifer, while the floodplain itself contributes $100 \times 10^{6} \mathrm{~m}^{3}$ /year to Lake Tana. The difference $\left(6 \times 10^{6} \mathrm{~m}^{3} /\right.$ year $)$ is being stored in the floodplain. However, the flow of water from the aquifer to the river is observed during the wet season, reversing the flow direction of the dry period. Similarly, a significant abstraction of river water by the floodplain had also been observed by Dessie et al. [12] and Kebede et al. [18]. Furthermore, the groundwater in the lake-shore aquifers did not show any sign of ${ }^{18} \mathrm{O}$ and ${ }^{2} \mathrm{H}$ enrichment caused by the possible admixing of lake water, showing an insignificant flow of lake water to the surrounding aquifer systems $[18,55,63]$. However, deeper wells (as deep as $100 \mathrm{~m}$ ) in the floodplain area (on volcanic aquifers) had the most depleted $\delta^{18} \mathrm{O}$ values, consistent with higher elevation precipitation, possibly indicating that their recharge is from the regional groundwater inflow from the far remote highland area [18]. Similar conclusions had been obtained by Kebede et al. [18] for the Seraba and Wanzaye springs (Figure 7), respectively, in the middle Rib and Gumara catchments.
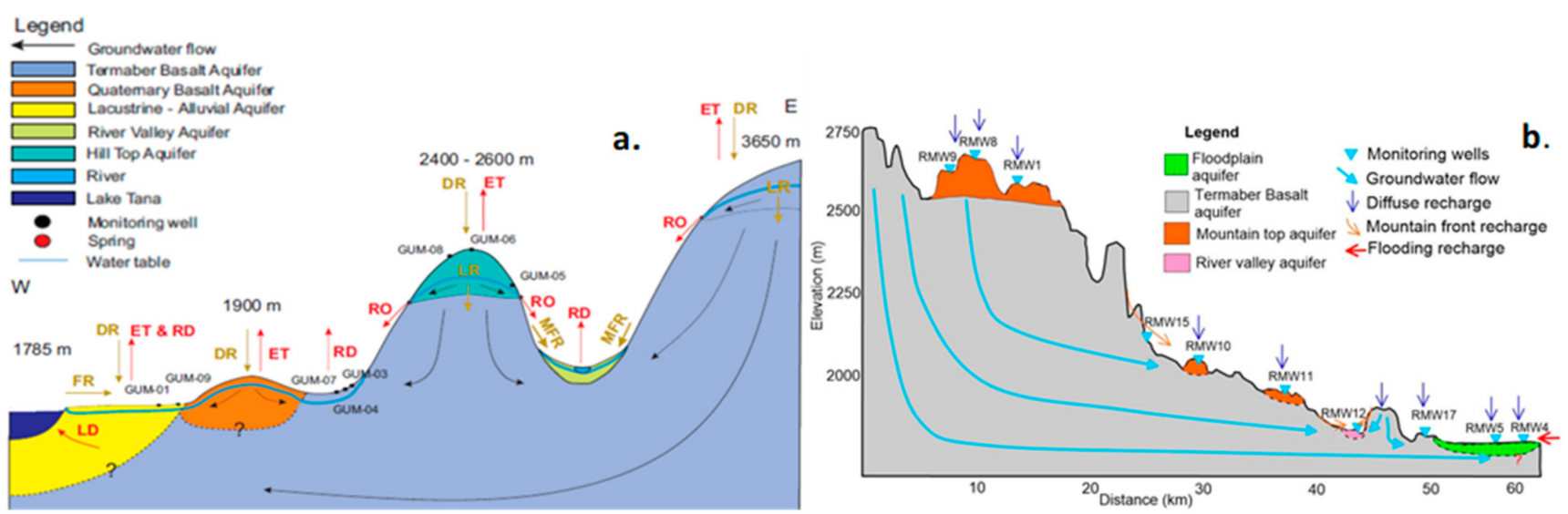

Figure 8. Hydrostratigraphical model for Gumara river catchment (a) (not to scale), and for Rib (b) with the different recharge/discharge mechanisms from the Guna shield mountain chain to the Lake Tana (after Van Landtschoote [64] and Getenet [43]), (DR = diffuse recharge, MFR = Mountain Front Recharge, LR = Leakage recharge, FR = Flooding recharge, $\mathrm{LD}=$ Lake discharge, $\mathrm{ET}=$ Evapotranspiration, $\mathrm{RD}=$ River Discharge, $\mathrm{RO}=$ groundwater discharge from springs .

\subsection{Hydrogeochemical and Stable Isotope Studies}

According to Kebede et al. [19], two major types of groundwater systems in the Upper Blue Nile Basin as well as in Lake Tana Basin were distinguished. The first is low salinity, $\mathrm{Ca}-\mathrm{Mg}-\mathrm{HCO}_{3}$ type, isotopically relatively enriched cold $\left(13-25^{\circ} \mathrm{C}\right)$ groundwaters from the basaltic plateau; and the second is high TDS, $\mathrm{Na}-\mathrm{HCO}_{3}$ type, isotopically relatively 
depleted, low temperature $\left(25-40{ }^{\circ} \mathrm{C}\right)$ thermal groundwater systems from the deeply faulted grabens. The former water type is the recharge area water or quickly moving groundwaters which lacks strong interaction with minerals in the rock (for example along with open fractures), while the latter type shows strong geochemical evolution. In the high TDS water, hydrolysis of silicate minerals by the $\mathrm{Ca}-\mathrm{Mg}-\mathrm{HCO}_{3}$ type waters leads to an increase of the concentration of $\mathrm{Na}, \mathrm{K}, \mathrm{Mg}$, and $\mathrm{HCO}_{3}[19,31]$. Increasing Ca concentration is inhibited by early time Ca saturation, leading to precipitation of carbonates. Similar results were found by Demlie et al. $[60,69]$ in the Addis Ababa area (on the rift margin plateau), by Alemayehu et al. [62] on a plateau in the Axum area, and by Ayenew et al. [70] and Yitbarek et al. [62] in the Awash basin, which are all on the volcanic plateau. The low TDS Ca- $-\mathrm{HCO}_{3}$ or $\mathrm{Ca}-\mathrm{Mg}-\mathrm{HCO}_{3}$ water is usually found on the topographic highs, while relatively high TDS cold $\mathrm{Na}-\mathrm{HCO}_{3}$ water type is found on topographic lows, and very high TDS is along deep-seated low-temperature hot springs [19,59-61,69,71]. However, the water type with low geochemical evolution is also found in the lowlands. This may be due to preferential flowing of water through open fractures without having much residence time for strong rock-water interaction. Similar results have been also obtained by Nigate et al. [29] for large. Similar to the result by Yitbarek et al. [62] in the plateau of Awash basin, Nigate et al. [29] found $\mathrm{NaHCO}_{3}$ water with relatively low TDS in a deep well at the upper Gilgel Abay catchment. Both studies explained it as it is due to the cation exchange of $\mathrm{Ca}^{+}$ by $\mathrm{Na}^{+}$in the thin clay beds intercalating the volcanic layers.

There are at least two geochemical types of groundwater within the general shallow aquifer system of the basaltic plateau, representing shallow circulation and relatively deeper circulation, whereby the concentration of all major parameters (except $\mathrm{SiO}_{2}$ and $\mathrm{Ca}^{2+}$, due to earlier saturation), the $\mathrm{pH}$, and the TDS increase from the former to the latter $[19,60]$. Using an integrated application of water isotopes, major ion chemistry, and $\delta^{13} \mathrm{C}$ values, different types of groundwater composition were identified by Kebede et al. [18]. High saline groundwater in the shallow aquifers of the floodplain was found by Kebede et al. [19] and Kebede et al. [18]. According to the latter study, the shallow groundwater around the wetlands area indicates no apparent ${ }^{18} \mathrm{O}$ enrichment and is similar to groundwaters in the adjacent basalt aquifers, precluding the role of evaporation in imparting salinity to the wetland shallow groundwater. Instead, explained that the salinity was due to the dissolution of salts from the alluvio-lacustrine sediments. The accumulation of salts is thought to take place in the pockets of evaporation pools dotting the floodplains. These saline waters are not found everywhere rather they are found localized in certain areas where such evaporation pools were located [18].

The Ethiopian plateau basins including the Upper Blue Nile Basin are characterized by high altitude, low mean annual air temperature, a long distance from the Atlantic moisture source. However, the recharge area groundwaters of the area do not show corresponding $\delta^{18} \mathrm{O}$ depletion compared to modern meteoric waters of Sahelian Africa $[19,60]$. This is similar to the findings by Rozanski et al. [72], and Joseph et al. [73], respectively, for East African rainfall and groundwater across Sahelian Africa. Unlike the groundwaters in the Ethiopian Rift, the groundwaters of the Upper Blue Nile Basin are characterized by high $(>15){ }^{2} \mathrm{H}$ excess [19]. Similar results were also obtained by Alemayehu et al. [61], Demlie et al. [60], Yitbarek et al. [62], and Nigate et al. [29] at different parts of the Ethiopian volcanic terrain. This $\delta^{2} \mathrm{H}$ excess in the groundwater could be due to the effect of evaporation before joining the groundwater [62]. The low-temperature thermal and the high TDS $\mathrm{Na}-\mathrm{HCO}_{3}$ type groundwaters in the fault grabens of Lake Tana Basin were found to have relatively highly depleted $\delta^{18} \mathrm{O}$ compositions and low tritium values, indicating recharge had taken place in the highland areas and it was recharged during former cold climate $[19,60]$. Hydrochemical and stable isotope signatures, supported with stratigraphic and hydrostratigraphic evidences, showed groundwater inflow from the adjacent Blue Nile plateau area to the Upper Awash Basin groundwater system through the lower basaltic regional aquifer [62], portraying inter-basin groundwater transfer between these two largest highland basins of Ethiopia. The subsurface regional fault systems, which may 
be acting as deep aquifer water conveyors, had been also noted by Ayenew et al. [59], Demlie et al. [60,74], Kebede et al. [19], and SOGREAH [58] between different basins in the Ethiopian volcanic plateau aquifers. This gives new insight and probable revision to the water balance estimation made in all basins including Lake Tana.

The presence of high partial pressure of $\mathrm{CO}_{2}$, high $\mathrm{HCO}_{3}{ }^{-}$, and usually high mineralization in the deep circulating groundwater system shows that there is a source of $\mathrm{CO}_{2}$ at depth. This could be a direct source from the mantle along the deep faults, or it could result from metamorphic decarbonation of the underlying limestone $[19,60,61]$. An exception is the Wanzaye low-temperature hot spring water system, located at the foothill of the Gumara catchment to the floodplain (Figure 7). While its isotopic signature indicates that it is from the old circulating deep aquifer system water [19], it has a very high $\mathrm{pH}$, the extremely low partial pressure of $\mathrm{CO}_{2}$, and very low TDS dominated by $\mathrm{Na}^{+}, \mathrm{HCO}_{3}, \mathrm{SiO}_{2}$, and with extremely low $\mathrm{Ca}^{2+}$ and $\mathrm{Mg}^{2+}$ cations. Kebede et al. [16] explained that these spring waters exist through interaction with a metamorphosed Miocene lacustrine lignite and mud rock beds embedded between the Trap Series basalts. This metamorphosed zone could act as a major sink zone for $\mathrm{CO}_{2}, \mathrm{Ca}^{2+}$ and $\mathrm{Mg}^{2+}$ with an increase in $\mathrm{Na}^{+}, \mathrm{K}^{+}, \mathrm{pH}$, and $\mathrm{SiO}_{2}$ leading to this unique characteristic [19]. However, we could not find any report that shows the presence of coal/mudrock beds near the spring or in any of the drillings in the downstream plain of the springs. Another unique spring water, which is highly depleted in $\delta^{18} \mathrm{O}$ and $\delta^{2} \mathrm{H}$ and highly mineralized chemistry (TDS $>7000 \mathrm{mg} / \mathrm{L}$ ), is the Sereba spring (Figure 7) which are also noted by Kebede et al. [18]. This groundwater might have been recharged at a higher altitude, perhaps in the former cold climate, and is emerging to the surface due to the blockage of the deeper groundwater circulation by volcanic plugs or dikes observed at the spring site. The source for the high TDS might be deeper water interaction with the Mesozoic sedimentary rocks unconformably underlying the Tertiary volcanic rocks [39,55]. Volcanic plugs and dikes are common in the Tana Basin $[40,56,58]$. Hence, similar groundwater types perhaps would have been more commonly found if detailed isotopic and chemical sampling and analysis had been performed.

\section{General Research Gaps in the Hydrogeology of Lake Tana Basin}

High spatial variability (mainly due to topography) and temporal variability (principally seasonal, but with small and opposite long-term trends at different gauging stations of rainfall) have been noted for the land part of Tana Basin [23] as well as over the lake $[13,24,26]$. Similarly, calculation of the areal rainfall from the measured point rainfall has significant uncertainty and is one of the challenges in hydrological modeling [42]. Hence, estimates of runoff and other hydrological terms are expected to incorporate substantial uncertainties. Furthermore, rainfall intensity has an important role in affecting runoff, infiltration, and other water balance terms [75-78]. Thus, it is one of the important model parameters that is calibrated in the hydrological models. However, since no study has been done so far about rainfall intensity only estimated values are assigned in the calibration processes of the hydrological modeling of the Lake Tana Basin and its catchments. Therefore, rainfall intensity should be studied by installing very fine time scale measuring gauges rather than total daily measurement. Above all, rainfall over the lake, which is about $50 \%$ of the total inflows to the lake but with significant spatial variation $[12-14,24,26,33]$, shall be better estimated by installing some more new gauges on the islands as well as at different sites on the lakeshore or nearby.

Similarly, data for the other meteorological variables such as $\mathrm{min} / \mathrm{max}$ temperature, wind speed, sunshine hours, and relative humidity which are important to calculate the evapotranspiration and lake evaporation, are poorly available given to the large areal extent of the study basin and the water balance sensitivity to these terms. Significant variation in estimated values of annual over-lake evaporation by various authors (Table 2), has been partly due to using different meteorological data sources, where a bit more meteorological station data have been added only in recent studies (e.g., in [12]. The high topographical variation leads to large differences in values for the different meteorological variables. 
Having a geographically well-distributed network of meteorological stations (especially $\mathrm{min} / \mathrm{max}$ temperature and precipitation) will help to estimate both inflows and outflows (evaporation) in a more accurate way. Direct measurement of lake water evaporation which Grabham and Black [22] tried using old techniques should be done in a continuous and more coordinated way using more recent technologies. Such measurements will help validate the calculations using long-term meteorological data. In addition, good estimates of precipitation and evapotranspiration will allow making more reliable groundwater recharge estimations (which is, in turn, important input data for groundwater modeling of the basin).

It is noted that one of the gaps in the water balance studies is the ungauged river inflow to the lake (Table 3), leading to significant uncertainties in the estimated water balances. Ungauged catchments could behave very differently from gauged catchments, mostly due to subsurface geological conditions [26]. Therefore, increasing river gauging stations, especially for rivers with relatively high flows in the northeastern and northwestern parts of the study area, is essential for updating the inflow amount, and hence the water balance.

Generally, the groundwater in the basin is less studied than the surface water (e.g., [18, $19,29,30,56])$. Most of these studies were concentrated on general geochemistry. However, the following aspects are either poorly studied or not studied at all.

- aquifer properties characterization such as transmissivity and hydraulic conductivity;

- groundwater flow system and groundwater balance;

- more detail surface-groundwater interactions studies with water bodies such as rivers, the lake, and wetlands

- groundwater potential and sustainability to possible natural (e.g., drought) and human exploitations.

Fortunately, there are high numbers of newly-built hand-dug wells and several new boreholes in recent years. These represent new data sources for physical hydrogeological studies as well as for sampling for further hydrochemical and isotope studies, which can partly fill the current data scarcity.

Finally, groundwater wells and springs with anomalous TDS (in the middle Rib catchment) and hot springs with extremely low TDS (unlike the other highland or rift hot springs), aforementioned by $[18,19]$ are not well justified and need a thorough study. Also requiring more study are the high sulfate concentrations in the floodplain boreholes that were found by Kebede et al. [18,19], but who offered little explanation regarding why and how they appeared and no information who offered little explanation regarding their spatial distribution. Furthermore, water usage for irrigation is growing fast in the floodplains as well as in the highlands. In addition, Eucalyptus tree coverage, whose evapotranspiration uptake is high, is expanding in the basin. Both these new activities affect the hydrology. Hence, updating the water balance of the basin is important, by considering these changing scenarios.

\section{Conclusions}

The Lake Tana Basin is identified as one of the few agricultural growth corridors of the country. Basin-wide surface-groundwater studies performed in the Lake Tana Basin are summarized in this review paper. In general, mean annual precipitation over the lake was estimated to have a range from $3784-4431 \times 10^{6} \mathrm{~m}^{3}$; lake evaporation of 3900$5547 \times 10^{6} \mathrm{~m}^{3}$; river inflow of 3500-6832 $\times 10^{6} \mathrm{~m}^{3}$; and river (lake) water outflow of $3399-5300 \times 10^{6} \mathrm{~m}^{3}$. In most of the studies (except Mamo [30]), groundwater inflow and outflow is considered insignificant. Hydrometeorological data scarcity (both spatially and temporally) is the critical limiting factor for the water balance studies of the lake. Hence, the present water balance studies have many discrepancies. In addition, the interaction between the surface water bodies and the groundwater has not been investigated in detail which could have led to different results for the water balance terms if significant interaction exists. 
Multi-layer aquifer systems interbedded with aquicludes result in high heterogeneity and anisotropy in the groundwater systems of the basin. Despite the natural complexity, there have been few groundwater studies in the area. In this review, the studies on groundwater recharge, aquifer characterization, and hydrochemistry of groundwater in the Lake Tana Basin with reference to some studies on the other plateau volcanic aquifers have been assessed. In general, two groups of groundwater are found in the Lake Tana basin: (1) low TDS, $\mathrm{Ca}-\mathrm{Mg}-\mathrm{HCO}_{3}$ type, isotopically relatively enriched cold $\left(13-25^{\circ} \mathrm{C}\right)$ groundwaters from the basaltic plateau; and (2) high TDS, $\mathrm{Na}-\mathrm{HCO}_{3}$ type, isotopically relatively depleted, low temperature $\left(25-40^{\circ} \mathrm{C}\right)$ thermal groundwater systems from the deeply faulted grabens. Within the general shallow aquifer system of the basaltic plateau, there are two groundwater types, representing shallow circulation and relatively deeper circulation, whereby the concentration of all major parameters, the $\mathrm{pH}$, and the TDS increase from the former to the latter. According to the limited studies, there is strong river water and groundwater interaction; however, based on some chemistry and stable isotope studies, the lake-groundwater interaction is insignificant. Groundwater recharge values estimated at different parts of the basin applying different techniques show high variation possibly due to strong spatial variability, and/or the disparity between the reality and the assumptions of the methods applied.

The different water balance studies have their own weakness and strength. Thus, it is difficult to conclude the result of any of the studies is accurate. However, given the methods followed to estimate the river inflows (the increasing of the gauging coverage and separate parameterization of the hilly and the floodplain parts), the water balance values estimated by Dessie et al. [8] might be more acceptable results. The groundwater outflow to the Beles basin result by Mamo [20] is a new insight, and at least gives a reason for the water balance discrepancy estimated by the other authors. The evaluation of the different groundwater recharge studies by Yenehun et al. [64], shows how the effectiveness of the different methods varies from place to place. Hence, estimating recharge using a single technique or averaging the values by different methods is less accepted. Values by using the WTF and other water level data-based methods are accepted in floodplains and values by water balance methods like the SMB on the sloping and plateau highland aquifers are more accepted.

Further detailed studies on the interaction of lake-groundwater as well as rivergroundwater are suggested. In addition, pumping test data, groundwater water level monitoring, and detailed litho-section studies will help to explicitly characterize the different layered aquifer systems and their interconnection. It is also very important to assess the sensitivity of the groundwater resource to climatic variations. Using this review work, researchers can easily identify the research gaps and refer to the investigated values, and the conclusions drawn.

Author Contributions: Software, A.Y. and A.S.B.; resources, K.W. and J.N.; writing—original draft preparation, A.Y.; writing-review and editing, K.W., M.D., J.N., E.A., M.A., F.N. and A.V.G.; visualization, F.N., A.S.B. and M.V.C.; supervision, K.W.; project administration, K.W.; M.D., J.N., E.A.; funding acquisition, J.N., K.W., E.A. and M.D. All authors have read and agreed to the published version of the manuscript.

Funding: This research was funded by VLIR-UOS of the Belgian Flemish Government, through BDU-IUC project.

Institutional Review Board Statement: Not applicable.

Informed Consent Statement: Not applicable.

Data Availability Statement: Not applicable.

Acknowledgments: This review paper is made under the financial support of the BDU-IUC project, funded by VLIR-UOS of the Belgian Flemish Government. Hence, we would like to thank VLIR-UOS for their financial support.

Conflicts of Interest: The authors declare no conflict of interest. 


\section{References}

1. Wheeler, K.G.; Hall, J.W.; Abdo, G.M.; Dadson, S.J.; Kasprzyk, J.R.; Smith, R.; Zagona, E.A. Exploring Cooperative Transboundary River Management Strategies for the Eastern Nile Basin. Water Resour. Res. 2018, 54, 9224-9254. [CrossRef]

2. Hussein, H.; Conker, A.; Grandi, M. Small is beautiful but not trendy: Understanding the allure of big hydraulic works in the Euphrates-Tigris and Nile waterscapes. Mediterr. Polit. 2020, 1-24. [CrossRef]

3. Conway, D. A water balance model of the Upper Blue Nile in Ethiopia. Hydrol. Sci. J. 1997, 42, 265-286. [CrossRef]

4. Kim, U.; Kaluarachchi, J.J. Climate change impacts on water resources in the upper Blue Nile River Basin, Ethiopia. J. Am. Water Resour. Assoc. 2009, 45, 1361-1378. [CrossRef]

5. Setegn, S.G.; Rayner, D.; Melesse, A.M.; Dargahi, B. Impact of climate change on the hydroclimatology of Lake Tana Basin, Ethiopia. Water Resour. Res. 2011, 47, W04511. [CrossRef]

6. Grandi, M. Hydropolitics in Transboundary Water Management Conflict, Cooperation and Governance along the Nile River, A Dissertation Submitted in Partial Fulfillment of the Requirements for the Degree of Doctor of Philosophy. Ph.D. Thesis, Human Rights and Sustainability Sant'Anna School of Advanced Studies, Pisa, Italy, 2016.

7. Hussein, H.; Grandi, M. Dynamic political contexts and power asymmetries: The cases of the Blue Nile and the Yarmouk Rivers. Int. Environ. Agreem. Polit. Law Econ. 2017, 17, 795-814. [CrossRef]

8. Wheeler, K.G.; Jeuland, M.; Hall, J.W.; Zagona, E.; Whittington, D. Understanding and managing new risks on the Nile with the Grand Ethiopian Renaissance Dam. Nat. Commun. 2020, 11, 5222. [CrossRef] [PubMed]

9. Setegn, S.G.; Srinivasan, R.; Melesse, A.M.; Dargahi, B. SWAT model application and prediction uncertainty analysis in the Lake Tana Basin, Ethiopia. Hydrol. Process. 2010, 24, 357-367. [CrossRef]

10. Gebremicael, T.G.; Mohamed, Y.A.; Betrie, G.D.; van der Zaag, P.; Teferi, E. Trend analysis of runoff and sediment fluxes in the Upper Blue Nile basin: A combined analysis of statistical tests, physically-based models and landuse maps. J. Hydrol. 2013, 482, 57-68. [CrossRef]

11. Dessie, M.; Verhoest, N.E.C.; Pauwels, V.R.N.; Admasu, T.; Poesen, J.; Adgo, E.; Deckers, J.; Nyssen, J. Analyzing runoff processes through conceptual hydrological modeling in the Upper Blue Nile Basin, Ethiopia. Hydrol. Earth Syst. Sci. 2014, 18, 5149-5167. [CrossRef]

12. Dessie, M.; Verhoest, N.E.C.; Pauwels, V.R.N.; Adgo, E.; Deckers, J.; Poesen, J.; Nyssen, J. Water balance of a lake with floodplain buffering: Lake Tana, Blue Nile Basin, Ethiopia. J. Hydrol. 2015, 522, 174-186. [CrossRef]

13. Rientjes, T.H.M.; Perera, B.U.J.; Haile, A.T.; Reggiani, P.; Muthuwatta, L.P. Regionalisation for lake level simulation-The case of Lake Tana in the Upper Blue Nile, Ethiopia. Hydrol. Earth Syst. Sci. 2011, 15, 1167-1183. [CrossRef]

14. Wale, A.; Rientjes, T.H.M.; Gieske, A.S.M.; Getachew, H.A. Ungauged catchment contributions to Lake Tana's water balance. Hydrol. Process. Int. J. 2009, 3693, 3682-3693. [CrossRef]

15. Dessie, M.; Verhoest, N.E.C.; Admasu, T.; Pauwels, V.R.N.; Poesen, J.; Adgo, E.; Deckers, J.; Nyssen, J. Effects of the floodplain on river discharge into Lake Tana (Ethiopia). J. Hydrol. 2014, 519, 699-710. [CrossRef]

16. Poppe, L.; Frankl, A.; Poesen, J.; Admasu, T.; Dessie, M.; Adgo, E.; Deckers, J.; Nyssen, J. Geomorphological map of the Lake Tana Basin (Ethiopia). J. Maps 2013, 9, 431-437. [CrossRef]

17. Alemayehu, T.; McCartney, M.; Kebede, S. The water resource implications of planned development in the Lake Tana catchment, Ethiopia. Ecohydrol. Hydrobiol. 2010, 10, 211-221. [CrossRef]

18. Kebede, S.; Admasu, G.; Travi, Y. Isotopes in Environmental and Health Studies Estimating ungauged catchment flows from Lake Tana floodplains, Ethiopia: An isotope hydrological approach. Isot. Environ.Health Stud. 2011, 47, 37-41. [CrossRef]

19. Kebede, S.; Travi, Y.; Alemayehu, T.; Ayenew, T. Groundwater recharge, circulation and geochemical evolution in the source region of the Blue Nile River, Ethiopia. Appl. Geochem. 2005, 20, 1658-1676. [CrossRef]

20. Dile, Y.T.; Tekleab, S.; Kaba, E.A.; Gebrehiwot, S.G.; Worqlul, A.W.; Bayabil, H.K.; Yimam, Y.T.; Tilahun, S.A.; Daggupati, P.; Karlberg, L.; et al. Advances in water resources research in the Upper Blue Nile basin and the way forward: A review. J. Hydrol. 2018, 560, 407-423. [CrossRef]

21. Tekleab, S.; Uhlenbrook, S.; Mohamed, Y.; Savenije, H.H.G.; Temesgen, M.; Wenninger, J. Water balance modeling of Upper Blue Nile catchments using a top-down approach. Hydrol. Earth Syst. Sci. 2011, 15, 2179-2193. [CrossRef]

22. Grabham, G.W.; Black, R.P. Report of the Mission to Lake Tana; Ministry of Public Works, Government Press: Cairo, Egypt, 1925.

23. Gedefaw, M.; Yan, D.; Wang, H.; Qin, T.; Girma, A.; Abiyu, A.; Batsuren, D. Innovative trend analysis of annual and seasonal rainfall variability in Amhara Regional State, Ethiopia. Atmosphere 2018, 9, 326. [CrossRef]

24. Haile, A.T.; Rientjes, T.; Gieske, A.; Gebremichael, M. Rainfall Variability over Mountainous and Adjacent Lake Areas: The Case of Lake Tana Basin at the Source of the Blue Nile River. J. Appl. Meteorol. Climatol. 2009, 48, 1696-1717. [CrossRef]

25. Tesemma, Z.K.; Mohamed, Y.A.; Steenhuis, T.S. Trends in rainfall and runoff in the Blue Nile Basin: 1964-2003. Hydrol. Process. 2010, 24, 3747-3758. [CrossRef]

26. SMEC. Hydrological Study of the Tana-Beles Sub-Basins: Surface Water Investigations; Ethiopian Ministry of Water and Energy: Addis Ababa, Ethiopia, 2008.

27. Abiy, A.Z.; Demissie, S.S.; Charlotte, M.; Dessu, S.B.; Melesse, A.M. Groundwater Recharge and Contribution to the Tana Sub-basin, Upper Blue Nile Basin, Ethiopia. In Landscape Dynamics, Soils and Hydrological Processes in Varied Climates; Springer: Berlin/Heidelber, Germany, 2016; pp. 463-481, ISBN 9783319187877. 
28. Kebede, S.; Travi, Y.; Alemayehu, T.; Marc, V. Water balance of Lake Tana and its sensitivity to fluctuations in rainfall, Blue Nile basin, Ethiopia. J. Hydrol. 2006, 316, 233-247. [CrossRef]

29. Nigate, F.; Van Camp, M.; Kebede, S.; Walraevens, K. Hydrologic interconnection between the volcanic aquifer and springs, Lake Tana basin on the Upper Blue Nile. J. Afr. Earth Sci. 2016, 121, 154-167. [CrossRef]

30. Mamo, S. Integrated Hydrological and Hydrogeological System Analysis of the Lake Tana Basin, Northwestern Ethiopia. Ph.D. Thesis, Addis Ababa University, Addis Ababa, Ethiopia, 2015.

31. Alemayehu, T.; Kebede, S. The role of geodiversity on the groundwater resource potential in the upper Blue Nile River Basin, Ethiopia. Environ. Earth Sci. 2011, 64, 1283-1291. [CrossRef]

32. Easton, Z.M.; Fuka, D.R.; White, E.D.; Collick, A.S.; Biruk Ashagre, B.; McCartney, M.; Awulachew, S.B.; Ahmed, A.A.; Steenhuis, T.S. A multi basin SWAT model analysis of runoff and sedimentation in the Blue Nile, Ethiopia. Hydrol. Earth Syst. Sci. 2010, 14, 1827-1841. [CrossRef]

33. Setegn, S.; Srinivasan, R.; Dargahi, B. Hydrological Modelling in the Lake Tana Basin, Ethiopia Using SWAT Model. Open Hydrol. J. 2008, 2, 49-62. [CrossRef]

34. Chorowicz, J.; Collet, B.; Bonavia, F.F.; Mohr, P.; Parrot, J.F.; Korme, T. The Tana basin, Ethiopia: Intra-plateau uplift, rifting and subsidence. Tectonophysics 1998, 295, 351-367. [CrossRef]

35. Jepsen, D.H.; Athearn, M.J. A General Geologic Map of the Blue Nile River Basin, Ethiopia (1:1,000,000); Department of Water Resources: Addis Ababa, Ethiopia, 1961.

36. Minucci, E. Ricerche geologiche nella regione del Tana. Missione di Studio al Lago Tana. R. Accad. Ital. 1938, 1, 37-46.

37. Baker, B.H.; Mohr, P.A.; Williams, L.A.J. Geology of the Eastern Rift System of Africa; The Geological Society of America, INC.: Boulder, CO, USA, 1972; ISBN 08137-2136-9.

38. Prave, A.R.; Bates, C.R.; Donaldson, C.H.; Toland, H.; Condon, D.J.; Mark, D.; Raub, T.D. Geology and Geochronology of the Tana Basin, Ethiopia: LIP volcanism, super eruptions and Eocene-Oligocene environmental change. Earrth and Planet. Sci. Lett. 2016, 443, 1-8. [CrossRef]

39. Pik, R.; Marty, B.; Carignan, J.; Lavé, J. Stability of the Upper Nile drainage network (Ethiopia) deduced from (U-Th)/He thermochronometry: Implications for uplift and erosion of the Afar plume dome. Earth Planet. Sci. Lett. 2003, 215, 73-88. [CrossRef]

40. Mohr, P.; Zanettin, B. The Ethiopian Flood Basalt Province; Springer: Dordrecht, The Netherlands, 1988.

41. Nigate, F.; Ayenew, T.; Belete, W.; Walraevens, K. Overview of the Hydrogeology and Groundwater Occurrence in the Lake Tana Basin, Upper Blue Nile River Basin. In Social and Ecological System Dynamics Krystyna Stave Goraw Goshu Shimelis Aynalem Editors Characteristics, Trends, and Integration in the Lake Tana Basin, Ethiopia; Springer: Cham, Switzerland, 2017; pp. 77-91.

42. Chebud, Y.A.; Melesse, A.M. Modelling lake stage and water balance of Lake Tana, Ethiopia. Hydrol. Process. 2009, 23, 3534-3544. [CrossRef]

43. Getenet, M. Hydrogeological Investigation and Groundwater Recharge Estimation of the Ribb River Catchment, Lake Tana basin, Upper Blue Nile, Ethiopia. Master's Thesis, Ghent University, Ghent, Belgium, 2017.

44. Hurni, H.; Tato, K.; Zeleke, G. The Implications of Changes in Population, Land Use, and Land Management for Surface Runoff in the Upper Nile Basin Area of Ethiopia. Mt. Res. Dev. 2005, 25, 147-154. [CrossRef]

45. Abdo, K. Assessment of Climate Change Impacts on the Hydrology of Gilgel Abay Catchment in Lake Tana basin, Ethiopia. Master's Thesis, International Institute for Geo-Information Science and Earth Observation Enschede, Enschede, The Netherlands, 2008.

46. Fiseha, B.M.; Alemseged, T.H.; Rientjes, T.H.M.; Gieske, A.S.M. Rainfall Estimation Using Satellite Remote Sensing and Ground Truth for Hydrologic Modelling over the Upper Blue Nile Region. In Hydrology and Ecology of the Nile River Basin under Extreme Conditions; Abitew, W., Melesesse, A.M., Eds.; Center for Labor Research and Studies, Florida International University: Miami, FL, USA, 2008; pp. 228-248.

47. Dinku, T.; Chidzambwa, S.; Ceccato, P.; Connor, S.J.; Ropelewski, C.F. Validation of high-resolution satellite rainfall products over complex terrain. Int. J. Remote Sens. 2008, 29, 4097-4110. [CrossRef]

48. Maidment, D.R. Handbook of Hydrology; McGRAW-Hill: New York, NY, USA, 1993.

49. Bakundukize, C.; Van Camp, M.; Walraevens, K. Estimation of Groundwater Recharge in Bugesera Region (Burundi) using Soil Moisture Budget Approach. Geol. Belg. 2011, 14, 85-102.

50. Kim, U.; Kaluarachchi, J.J. Application of parameter estimation and regionalization methodologies to ungauged basins of the Upper Blue Nile River Basin, Ethiopia. J. Hydrol. 2008, 362, 39-56. [CrossRef]

51. Azeze, M.; Seleshi, Y.; Eckstädt, H. Application of Stochastic Analysis and Modeling Techniques in Simulating the outflow series from Lake Tana catchment, Ethiopia. Int. J. Curr. Res. 2013, 5, 1577-1581.

52. Pietrangeli, S. Hydrological Report; Government of Ethiopia: Addis Abeba, Ethiopia, 1990.

53. Kaba, E.A. Validation of Altimetry Lake Level Data and Its Application in Water Resources Management. Master's Thesis, ITC, Enschede, The Netherlands, 2007.

54. Enku, T.; Melesse, A.M.; Ayana, E.K.; Tilahun, S.A.; Abate, M.; Steenhuis, T.S. Groundwater Evaporation and Recharge for a Floodplain in a Sub-humid Monsoon Climate in Ethiopia. L. Degrad. Dev. 2017, 1841, 1831-1841. [CrossRef]

55. Kebede, S.; Travi, Y.; Rozanski, K. The $\delta^{18} \mathrm{O}$ and $\delta^{2} \mathrm{H}$ enrichment of Ethiopian lakes. J. Hydrol. 2009, 365, 173-182. [CrossRef] 
56. SMEC. Hydrological Study of the Tana-Beles Sub-Basins: Groundwater Investigation; Ethiopian Ministry of Water and Energy: Addis Ababa, Ethiopia, 2008.

57. Hautot, S. The structure of a Mesozoic basin beneath the Lake Tana area, Ethiopia, revealed by magnetotelluric imaging. J. Afr. Earth Sci. 2006, 44, 331-338. [CrossRef]

58. SOGREAH. Detailed Groundwater Investigations \& Monitoring in Tana and Beles Sub-Basins, Volume I-Part 4: Geophysical Survey; Ministry of Water Resources: Addis Ababa, Ethiopia, 2013; Volume I.

59. Ayenew, T.; Demlie, M.; Wohnlich, S. Hydrogeological framework and occurrence of groundwater in the Ethiopian aquifers. J. Afr. Earth Sci. 2008, 52, 97-113. [CrossRef]

60. Demlie, M.; Wohnlich, S.; Ayenew, T. Major ion hydrochemistry and environmental isotope signatures as a tool in assessing groundwater occurrence and its dynamics in a fractured volcanic aquifer system located within a heavily urbanized catchment, central Ethiopia. J. Hydrol. 2008, 353, 175-188. [CrossRef]

61. Alemayehu, T.; Leis, A.; Eisenhauer, A.; Dietzel, M. Multi-proxy approach $\left({ }^{2} \mathrm{H} / \mathrm{H},{ }^{18} \mathrm{O} /{ }^{16} \mathrm{O},{ }^{13} \mathrm{C} /{ }^{12} \mathrm{C}\right.$ and $\left.{ }^{87} \mathrm{Sr} /{ }^{86} \mathrm{Sr}\right)$ for the evolution of carbonate-rich groundwater in basalt dominated aquifer of Axum area, northern Ethiopia. Chem. Der Erde 2011, 71, 177-187. [CrossRef]

62. Yitbarek, A.; Razack, M.; Ayenew, T.; Zemedagegnehu, E.; Azagegn, T. Hydrogeological and hydrochemical framework of Upper Awash River basin, Ethiopia: With special emphasis on inter-basins groundwater transfer between Blue Nile and Awash Rivers. J. Afr. Earth Sci. 2012, 65, 46-60. [CrossRef]

63. Kebede, S.; Abdalla, O.; Sefelnasr, A.; Tindimugaya, C.; Mustafa, O. Interaction of surface water and groundwater in the Nile River basin: Isotopic and piezometric evidence. Hydrogeol. J. 2017, 25, 707-726. [CrossRef]

64. Van Handtschoote, A. Hydrogeological Investigation and Recharge Estimation of Gumara River Catchment in Lake Tana basin, Northern Ethiopia. Master's Thesis, Laboratory of Applied Geology and Hydrogeology, Ghent University, Ghent, Belgium, 2017.

65. Yenehun, A.; Nigate, F.; Belay, A.S.; Desta, M.T.; Van Camp, M.; Walraevens, K. Groundwater recharge and water table response to changing conditions for aquifers at different physiography: The case of a semi-humid river catchment, northwestern highlands of Ethiopia. Sci. Total Environ. 2020, 748, 142243. [CrossRef]

66. Walker, D.; Parkin, G.; Schmitter, P.; Gowing, J.; Tilahun, S.A.; Haile, A.T.; Yimam, A.Y. Insights From a Multi-Method Recharge Estimation Comparison Study. Groundwater 2019, 57, 245-258. [CrossRef]

67. Van Griensven, A.; Ndomba, P.; Yalew, S.; Kilonzo, F. Critical review of SWAT applications in the upper Nile basin countries. Hydrol. Process. 2012, 16, 3371-3381. [CrossRef]

68. Beyene, A.A.; Verhoest, N.E.C.; Tilahun, S.; Alamirew, T.; Adgo, E.; Nyssen, J. Irrigation efficiency and shallow groundwater in anisotropic floodplain soils near Lake Tana, Ethiopia. Irrig. Drain. 2019, 68, 365-378. [CrossRef]

69. Demlie, M.; Wohnlich, S.; Wisotzky, F.; Gizaw, B. Groundwater recharge, flow and hydrogeochemical evolution in a complex volcanic aquifer system, central Ethiopia. Hydrogeol. J. 2007, 15, 1169-1181. [CrossRef]

70. Ayenew, T.; Kebede, S.; Tamiru, A. Environmental isotopes and hydrochemical study applied to surface water and groundwater interaction in the Awash River basin. Hydrol. Process. 2008, 22, 1548-1563. [CrossRef]

71. Ayenew, T. Major Ions Composition of the Groundwater and Surface Water Systems and Their Geological and Geochemical. SINET 2005, 28, 171-188.

72. Rozanski, K.; Araguas-Araguas, L.; Gonfiantini, R. Isotope Patterns of Precipitation in the East African Region. In The Limnology, Climatology and Paleroclimatology of the East African Lakes; Johnson, T.C., Odada, E.O., Eds.; Taylor and Francis: London, UK, 1996; pp. 79-93, ISBN 9780203748978.

73. Joseph, A.; Frangi, J.P.; Aranyossy, J.F. Isotope characteristics of meteoric water and groundwater in the Sahelo-Sudanese zone. J. Geophys. Res. Atmos. 1992, 97, 7543-7551. [CrossRef]

74. Demlie, M.; Ayenew, T.; Wohnlich, S. Comprehensive hydrological and hydrogeological study of topographically closed lakes in highland Ethiopia: The case of Hayq and Ardibo. J. Hydrol. 2007, 339, 145-158. [CrossRef]

75. Bochet, E.; Poesen, J.; Rubio, J.L. Runoff and soil loss under individual plants of a semi-arid Mediterranean shrubland: Influence of plant morphology and rainfall intensity. Earth Surf. Process. Landforms 2006, 31, 536-549. [CrossRef]

76. Dunkerley, D. Effects of rainfall intensity fluctuations on infiltration and runoff: Rainfall simulation on dryland soils, Fowlers Gap, Australia. Hydrol. Process. 2012, 26, 2211-2224. [CrossRef]

77. Jan, C.D.; Chen, T.H.; Lo, W.C. Effect of rainfall intensity and distribution on groundwater level fluctuations. J. Hydrol. 2007, 332, 348-360. [CrossRef]

78. Mu, W.; Yu, F.; Li, C.; Xie, Y.; Tian, J.; Liu, J.; Zhao, N. Effects of rainfall intensity and slope gradient on runoff and soil moisture content on different growing stages of spring maize. Water 2015, 7, 2990-3008. [CrossRef] 